\title{
Sociogeneze přemyslovského knížectví: Teorie Norberta Eliase a raný český stát ${ }^{*}$
}

\author{
JAN KALENDA**
}

The Sociogenesis of the Přemyslid Principality: Norbert Elias's Theory and Early Czech State

\begin{abstract}
This study deals with application of the Norbert Elias's theory of sociogenesis to the case of early Czech state formation. For this purpose we focus on the mechanisms of emergence and establishing of the state monopoly, as well as on the aspects of decentralization and privatization of state power during reign of first Přemyslid dukes - from 860 to $1230 \mathrm{AD}$. In the second place, the article tries to compare the process of sociogenesis in the Western Europe with the dynamics of state formation that was typical for the contemporary Czech lands. In this context we claim that Elias made several mistakes, because he supposed that features and mechanisms of state formation were fairly unitary everywhere Europe. We try to challenge this notion show that the history of state making in the Central European region has many autonomous and unique aspects that differentiate it from social dynamics in other parts of the continent. From this critical pointof view, the article attempts a reformulation of Elias's theory for the Central European area.
\end{abstract}

Klíčová slova: Norbert Elias, state formation, Přemysl's kingdom, civilizing proces, early medieval state, central Europe.

\section{Úvod}

Problematika vzniku a vývoje raného českého státu - vstupu Čechů do dějin, jak jej nazval historik Dušan Třeštík [2008] - patří již dlouhodobě k významným tématům tuzemského dějepisectví. V jeho rámci se spojují poznatky jak medievalistiky, tak i mnoha dalších př́buzných věd: archeologie, antropologie či lingvistiky. Na druhou stranu, z pohledu historické sociologie, jde o téma téměř netknuté, které zůstává dlouhodobě stranou zájmu nejenom domácích (historických) sociologů, ale i těch zahraničních. Zde předložená studie nechce nad tímto stavem pouze prázdně lamentovat (zamýšlet se nad „dialogem mezi hluchými“, jak jej nedávno pojmenoval Jiří Šubrt [2008]), nýbrž chce z tohoto dosavadního rozporu pokud možno co nejvíce těžit, a to v podstatě ve dvou ohledech: za prvé, chce obohatit poznání soudobé historické sociologie, konkrétněji řečeno problematiku formování evropských států, o poznatky českého dějepisectví. Toho chce dosáhnout mimo jiné tím, že je začlení do jednoho z uznávaných teoretických př́istupů, jímž je koncepce formování států německého sociologa Norberta Eliase. Za druhé, pokusí se Eliasovu teorii rekonstruovat tak, aby vyhovovala empirické podobě procesů, jež se odehrávaly v českém regionu. $\mathrm{Z}$ poznatků soudobé české historiografie, jak budeme ještě několikrát v průběhu textu argumentovat, totiž vyplývá, že mnoho z procesů, které mají mít podle Eliase univerzální charakter po celém světadíle, v prrípadě vývoje střední Evropy neplatí.

\footnotetext{
Za pročtení tohoto textu a neocenitelné rady děkuji zvláště Stanislavu Holubcovi, Anitě Moen a Jiřímu Šubrtovi.

** Veškerou korespondenci zasílejte na adresu Katedra sociologie a andragogiky, Filozofická fakulta, Univerzita Palackého Olomouc, tř. Svobody 26, 77200 Olomouc. E-mail: jankalenda@seznam.cz.
} 
K výběru teorie zmíněného autora nás vedou přinejmenším dva podstatné důvody: jednak z toho důvodu, že jeho koncepce je nesmazatelně zapsána do análů soudobé historicky orientované sociologie, že tedy dnes prakticky náleží k jejím kanonickým textům [viz např. Mertucelli 2008: kap. 6.; Smith 2001; Szakolczai 2000: 7-25], jednak na její odkaz navazuje celá řada pokračovatelů [např. Mennel 1989]. Z posledních pokusů využít eliasovského dědictví k analýze společenských procesů bychom mohli kupříkladu uvést článek Civilizační proces a jeho nespojitosti: sebevražda a zločiny vưči osobám ve Francii, 1825-1830, otištěný v nedávné době v časopise American Journal of Sociology [Whitt 2010]. Kromě toho je Eliasovo dílo - především díky výkladu Jiř́ho Šubrta [1996, 2007] - v Čechách velmi dobře známo. Tudíž k jeho aplikaci na zkoumání sociální dynamiky ve střední Evropě vybízí nejenom jeho mezinárodní kredit, ale i kladná domácí recepce. Právě z tohoto důvodu se domníváme, že využití Eliasovy teorie bude v tomto př́ípadě účelnější než adaptace jiných, méně známých teorií [viz např. Ertman 1997; Mann 1986].

Hlavním záměrem naší stati je podrobit zkoumání aplikaci Eliasovy teorie formování států (teorie sociogeneze) na vývoj přemyslovského knížectví mezi lety 860 až 1230 . Skrze ideová východiska a klíčové postuláty této koncepce chceme zjistit, nakolik je autorův univerzální model vývoje států platný i pro zdejší oblast a nakolik se od něj v konečném důsledku liší. Rovněž z tohoto důvodu má pak naše studie určitý komparativní rozměr, nebot’ se zamýšlí nad hlavními rozdíly mezi utvářením států v západní Evropě, na niž se ve svém vlastním bádání Elias převážně soustředil, a v Evropě střední, respektive východní. ${ }^{1} \mathrm{Na}$ základě rozdílů mezi autorovou teorií a sociálními procesy, jak jsou interpretovány domácí historiografií v oblasti české kotliny chceme v závěru textu naznačit možnou reformulaci teorie sociogeneze pro zdejší region.

Kromě těchto vzájemně propojených cílů bychom se měli ještě zmínit o některých důvodech, jež nás k jejich formulaci vedou a které mají důležitý teoretický a metateoretický přesah. Jinými slovy řečeno, půjde fakticky o některé z implicitních cílů, jež naše stat přináší. Nejdříve proto krátce pojednáme o metateoretických východiscích a s nimi spojených záměrech, posléze věnujeme určitý prostor i těm východiskům, jež souvisejí se stavem současné odborné debaty ohledně formování států a vztahu naší výzkumné aktivity k ní.

Thomas Kuhn [1997] se svém slavném spisu o vědeckých revolucích tvrdil, že jedním ze způsobů jak dělat „normální" vědu, je postupně rozšiřovat sféru poznatků stávajícího paradigmatu na stále širší okruh fenoménů, čímž má v rámci panujícího vědeckého obrazu světa docházet k akumulaci poznatků, a to obvykle až do bodu, v němž začíná toto rozšiřování selhávat a začínají se objevovat první anomálie odporující předcházejícím zjištěním. Jiný metodolog vědy, Karl R. Popper [1998], přišel s názorem, podle něhož je podstata pravdivosti vědeckých tvrzení spojena s tzv. falzifikací: aby byla teorie pravdivá, musí být potenciálně falzifikovatelná. Podstata velké části vědecké práce tak podle Poppera spočívá ve vyvracení stávajících teoretických koncepcí, čímž je zároveň zaručován vědecký pokrok,

1 V historiografii a samozřejmě i v historické sociologii můžeme nalézt různé označení pro území, které se nachází východně od Labe, či někdy dokonce východně od Rýna. V této studii se (pro něj) přidržujeme označení stř̌ední Evropa, nebot tento region, do něhož řadíme Čechy, Polsko a tehdejší Uhry, disponoval naprosto zvláštním vzorcem utváření raných států, který se podle historiků [např. Třeštík 1987, 2001; Wihoda 2006; Žemlič̌k 2002a: 35nn] lišil od formování států v jiných částech světadílu. Nicméně v širších geograficko-historických souvislostech šlo samozřejmě o součást východní Evropy. Tedy toho teritoria, jež se v předcházejících staletích vyvíjelo mimo sféru Říše římské. 
jelikož staré teorie jsou nahrazovány novějšími, těmi adekvátnějšími. Myšlenky obou zmíněných autorů různým způsobem figurují i v této stati. Na jednu stranu totiž usilujeme o rozšíření stávajícího teoretického modelu na širší sféru dat, než tomu bylo doposavad. V tomto případě jde dokonce o doslovné rozšíření, nebot Eliasovu teorii aplikujeme na širší zeměpisný rámec: opouštíme perimetr západní Evropy a vydáváme se vstříc Východu. Na druhou stranu právě skrze toto „rozšíření, prostřednictvím aplikace dané teorie v odlišném prostředí či systému, se ji pokoušíme falzifikovat. V celkovém záměru naší studie se tak stýká myšlenka z části kuhnovská a z části popperovská.

Co se soudobé kritické debaty o teoriích vývoje státu týká, rozcházíme se s pojetím, v němž byla západní část kontinentu považována za předobraz formačních procesů ve východní polovině světadílu, za jejich šablonu, která bude dříve či později tamějšími zeměmi napodobena [viz např. Giddens 1985; Poggi 1978; Parsons 1971; Teschke 2003, 2004; částečně pak i Elias 2007]. Oproti tomuto homogennímu pohledu na daný proces (lépe řečeno procesy) se zaměřujeme na hledání unikátní vývojové cesty, kterou nastoupily středoevropské země, konkrétně Čechy, jež pro tento př́ípad považujeme za jejich částečného reprezentanta. Jinak řečeno preferujeme pohled, v němž různorodost vývojových trajektorií vítězí nad jejich údajnou stejnorodostí. Pakliže bychom užili paralelu k jednomu ze soudobých pojetí modernity [Eisenstadt 2000; česky srovnej napřr. Arnason 2010], mohli bychom uvést, že ani v kontextu tradičních společností by se nemělo uvažovat pouze o jediné tradiční společnosti, nýbrž o celé řadě jejích časoprostorově vázaných podob s relativně nezávislou společenskou dynamikou, o multiple tradition societies, kdybychom tedy danou paralelu dovedli důsledně do konce.

Druhý, nikoliv nepodstatný podnět pro naši analýzu představuje nezbytnost zmapovat utváření států před závěrem prvního milénia našeho letopočtu, což je oblast, tentokrát nikoli prostorově, nýbrž časově ohraničená, budící další rozpory. Většina stávajících teorií má totiž tendenci období od 6. do 11. století přehlížet: prakticky se jeho zkoumání bud' nikterak nevěnuje, anebo pakliže ho do svých výzkumů zahrnuje, má tendenci jeho význam bagatelizovat, popř́padě se mu věnuje jen ledabyle. Díky takovémuto postupu začíná v historické sociologii vznikat zvláštní a stále se šírící mezera mezi dvěma oblastmi výzkumu: bádáním o vzniku států a bádáním o utváření raně novověkých státních režimů. Obě oblasti se sice věnují formování států, nicméně každá z nich stojí na opačné straně vznikající teoretické propasti. Zatímco teorie vzniku či původu států [např. Clastres 1977; Claessen, Skalnik 1978; česky např. Diamond 2001; Tainter 2009] konceptualizují procesy, které stály za přechodem od kmenových politických (a někdy i apolitických) struktur k protostátním a státním strukturám na úsvitu civilizací a těží především ze spojenectví $\mathrm{s}$ antropologií, teorie zaměřené na vyspívání raně moderních státních mašinérií (16. až 18. století) upínají svůj pohled na rozvoj mechanismů ve skoro moderních státech [např. Bourdieu 1998: kap. 4; Gorski 2003, Moore 1966; Skocpol 1979]. Jestliže se badatelé přeci jenom věnují ére raného středověku, zpravidla zahajují své analýzy až po roce 1000 [např. Mann 1986; Tilly 1992] a rozdíly mezi procesy v 9. a kupř́ikladu ve 12. století zjednodušují takovým způsobem, jaký by si při srovnávání procesů v 18. a například 19. století nikdy nedovolili. Vưči takovémuto pojetí, podobně jako v předcházejícím př́padě, se ostře vymezujeme.

Když tedy výše naznačené analýzy shrneme, v pozadí cílů naší stati lze nalézt dvě důležitá východiska spojená se snahou o zkoumání doposud přehlížených časových 
a prostorových aspektů formování evropských států. To je ostatně také bod, v němž se myšlenky vzešlé z kritiky stávajících teorií setkávají s našimi metateoretickými východisky (viz také výše).

Soubor hlavních, stejně tak jako zmíněných podružných cílů nás vede k určité redukci výzkumného záměru, což se projevuje mimo jiné tím, že se zaměřujeme na formační procesy, jež se odehrávaly jen během 9. až 13. století, nikoliv tedy dříve, ani později. Zmíněné časové omezení si z části vyžaduje teoretický záměr studie, z další části vychází z nutnosti omezení celkového rozsahu stati a nakonec je provázáno se specifickou dynamikou raně středověkého českého státu i s charakterem teorie Norberta Eliase.

Období 9. až 13. století, respektive léta 860 až 1230, bývají v kontextu českých dějin označována jakožto doba Čech knižecích [viz Žemlička 2002a], ${ }^{2}$ během níž přemyslovští vladaři nedisponovali - ve vztahu k zahraničním mocenským subjektům - zcela plnohodnotnou suverenitou, nacházeli se totiž v částečném vztahu závislosti nejdříve na Velkomoravské říši a poté na Řiši. Z této semiautonomní pozice se jim podařilo nadobro vyváznout až během vlády Přemysla Otakara I., který získal pro zdejší panovnickou doménu dědičný královský titul a s ním i de iure mezinárodní autonomii [Agnew 2008: 39]. Právě z tohoto důvodu ohraničujeme naše zkoumání rokem 860 na jedné straně, tedy vstupem prvních prameny potvrzených přemyslovských knížat do dějin, a ukončujeme jej na druhé straně rokem 1230, tj. smrtí Přemysla Otakara I., po níž nastupuje éra Čech královských [Žemlička 2002b]. ${ }^{3}$ Takovéto vymezení poměrně dobře koresponduje se stavbou Eliasovy teorie sociogeneze, která se skládá z analýzy dvou na sebe navazujících etap. Zatímco ta prvá spadá do období 9. až 14. století, druhá se rozkládá přes 15 až 18 . století. Obě etapy se přitom od sebe liší především svým hospodářským charakterem, jenž vytváří některé $\mathrm{z}$ hlavní předpokladů formačních procesů. Právě z tohoto důvodu se budeme věnovat pouze prvnímu období sociogeneze, které na rozdíl od původního Eliasova vymezení zkrátíme ještě o jedno století, na čas od 9. do 13. století. Zmíněné časové ohraničení je nezbytné pro náš komparativní záměr, jenž obsahuje rovněž srovnávání procesů odehrávajících se ve východní a západní části kontinentu.

Struktura navazujícího textu sleduje následující body, které jsme do různé míry podrobnosti rozvedli o něco výše: za prvé, věnujeme se vymezení Eliasovy teorie sociogeneze, jejím teoretickým východiskům, centrálním postulátům, a to především s ohledem na identifikaci prŕíinného řetězce, jenž podle Eliase stojí za raným formováním evropských států, včetně jeho konkrétního průběhu. Za druhé, upínáme naši pozornost k popisu hlavních rysů utváření států v západní Evropě, za jejíž reprezentanty, jak ostatně naznačuje sám Elias, považujeme Anglii a Francii. To vše s ohledem na procesy, které zde probíhaly během 9. až 13. století, zmíněné př́iklady přitom slouží v prvé řadě coby ilustrace badatelových teoretických tvrzení. Za třetí, popisujeme formační procesy v Čechách v identickém období, a sice s tím rozdílem, že je srovnáváme jak s Eliasovou teorií, tak i s procesy,

2 Ačkoliv musíme dodat, že sám Žemlička používá tento název pro kratší časový úsek, než to činíme my, tzn. jen pro léta 1034 až 1198, pro jakési „dlouhé dvanácté stoleti“, kdybychom použili hobsbawmovského příměru.

3 Uznáváme, že takováto periodizace klade mnohem vyšší důraz na sociálněpolitické struktury a uspořádání než na sociálněekonomické aspekty, které jsou charakteristické pro marxisticky orientované badatele a koncepce. Nicméně právě proto, že se naše studie v prvé řadě zaměřuje na roli politické dynamiky - a to jak té vnitrostátní, tak mezistátní - soudíme, že je pro naše úvahy vhodnější. To je také důvodem, proč na tomto místě neoperujeme s pojmy raný a vrcholný feudalismus. 
které se odehrávaly v oblasti blíže k Atlantiku. Poslední kapitola bude vyhrazena diskusi o našich zjištěních a reformulaci koncepce sociogeneze pro oblast Čech, a jak se domníváme, v určitých ohledech rovněž pro ostatní stř̌edoevropské státy (Uhry a Polsko).

\section{Eliasova teorie sociogeneze}

Podle Norberta Eliase [2007] představuje proces formování států, tzv. sociogeneze, mechanismemus, skrze jehož působení dochází ke stále vyšší úrovni koncentrace prostředků přinucení v rukou jediného sociálního subjektu, a sice státu. Tento proces podle něj započal po rozpadu Karolinské ř́šse (roku 843) a ve svých základních obrysech vyvrcholil nastolením absolutistických režimů o několik století později. Navíc, což je neméně důležité, je součástí mnohem šiřeji pojatého civilizačního procesu, během něhož dochází k postupnému nárůstu jak celkové sociální kázně na jedné straně, tak sebekontroly ze strany jedincova superega na straně druhé. Propojují se v něm tedy koncepty pojmenované jakožto společenská fylogeneze (vývoj kontroly v rámci společnosti jako celku) a ontogeneze (vývoj sociálně-psychologických charakteristik jedinců). Sociogeneze státu tak coby jeden z civilizačních subprocesů vytváří určité makrosociální - strukturální - podmínky pro posílení sociálního dohledu a sebe-usměrňování tendencí libida. Díky němu jsou mnohé z prostř̌edků fyzického nátlaku zaměňovány za čistě symbolické formy [srov. Elias 1978, 2006; Fountaine 1978; Smith 2001: 22]. V rámci naší stati se budeme primárně věnovat pouze těm aspektům Eliasovy teorie, jež jsou spojeny s problematikou sociogeneze, tematiky civilizačního procesu se tudíž dotkneme pouze okrajově. Navíc, aby bylo naše vymezení na tomto místě úplné, se budeme věnovat jen první části procesu sociogeneze, která spadá mezi 9. až 13. století a koreluje tak s našimi záměry (viz výše). V dalších podkapitolách se proto postupně zaměříme na ideové zdroje autorovy koncepce, dále pak na příčiny (či předpoklady) formování států a stejně tak rovněž na jeho ústř̌ední složky, jimiž rozumíme popis principů fungování tzv. monopolního mechanismu, v neposlední řadě se zastavíme také u determinant a konečných důsledků celého procesu.

\section{Ideové zdroje autorovy koncepce}

Eliasovské pojetí utváření státních organizací navazuje na jednu z nejvýznamnějších tradic zkoumání vývoje států - na teorii Maxe Webera [1998 (1922): 247] a některých německých dějepisců [Hintze 1975 (1902-1909)], zejména pak na jejich pojetí státu jakožto lidské pospolitosti, jež si na určitém území nárokuje monopol legitimní fyzické moci. Takovéto pojetí Elias de facto přijímá, což má důležité teoretické konsekvence: kupř́íkladu to, že raně středověký stát, nebo méně specificky „politický systém“, jemuž se zde věnujeme, je podle něj vlastně „ne-státem“, jelikož postrádá onen důležitý monopol. Vývoj státu, pakliže má nějakou ústřední vývojovou linii, představuje podle Eliase pohyb od tohoto feudální „ne-státu“k Weberově pospolitosti nárokující si výhradní monopol na užití donucujících prostředků na vlastním území. I proto nazývá Elias mechanismus utváření raných

Takovéto vymezení státu není samozřejmě jediné možné. Jak kupř́ikladu dokládá Ernest Gellner [1993: 14], podle něhož existují státy nebo rozhodně instituce, které bychom normálně byli nakloněni takto nazývat, jež nemonopolizují legitimní násilí uvnitř svého území, které více nebo méně účinně ovládají. To je podle Gellnera zároveň exemplární prrípad feudálních států. Podobné stanovisko jako on pak zastává i historička 
států monopolním a Weberovu chápání se rovněž podobá jeho pojetí politiky, již lze v Eliasově prrípadě definovat coby snahu o zisk podílu na moci, anebo alespoň na vlivu při jejím přerozdělení, at už mezi státy nebo mezi skupinami nacházejícími se uvnitř států. (To je akcent, který se budeme snažit udržet v rámci celé stati.) Dalším důležitým Eliasovým inspiračním zdrojem se v případě procesu sociogeneze stal Karel Marx [např. Marx, Engels 1952] a jeho pojetí společenskohistorických formací, konkrétně zvláště té feudální. Podobně jako Marx se i Elias domnívá, že pro formování států je důležitá charakteristika hospodářské základny, jež podmiňuje moc, kterou jednotliví aktéři vnitropolitických bojů disponují. V tomto ohledu Elias rozlišuje dva typy společenskoekonomických řádů: naturální a monetární ekonomiku. Každá z nich, sama o sobě, výrazným zpo̊sobem transformuje (či konzervuje) rozložení politických sil, čímž podstatným zpơsobem proměňuje i charakter soupeření různých společenských skupin o podíl na moci, a rovněž o podobu státu jako takového. My se budeme převážně věnovat klíčovým znakům první z hospodářských formací, tedy naturální ekonomice, která v etapě mezi 9. až 13. stoletím převažuje. ${ }^{5}$ Posledním $\mathrm{z}$ inspiračních zdrojů, jemuž se však v případě teorie sociogeneze nedostává tolik prostoru jako předcházejícím dvěma, byl pro Eliase Sigmund Freud a jeho psychoanalytická teorie. Freudovy [1998 (1930)] myšlenky jsou pak nejvíce přítomné v těch fázích, když se Elias snaží zdůraznit vliv státu na utváření superega běžných jedinců, jeho obyvatel.

\section{Příčiny formování států}

Již jsme stačili uvést, že procesy utváření státních organizací na evropském kontinentu spojuje Elias s rozpadem Karolinské říše v polovině 9. století, což je také jedna z jejich hlavních přičin. Tou druhou jsou demografické procesy, které se začínají rozvíjet zejména od poloviny 11. století. Nejdříve se ale zastavíme u těch aspektů, jež jsou provázány s politickou dezintegrací a které vyvolal rozpad Západofrancké ř́šse, a o něco později se zaměříme i na populační trendy zasahující do zmíněné dynamiky.

Po roce 843 se bývalá Západofranská ř́iše rozdrolila do desítek více či méně drobných panství pod správou různě silných velmožů, kteří se stali nezávislými na jakékoliv ústřední moci. Jinými slovy došlo k částečné (a místy ke zcela kompletní) privatizaci panovnické/státní moci, k její dekoncentraci, ke zhroucení monopolu státu na organizované násilí [Elias 2007: 107]. Sociální organizace vystavěná na bázi post-antického státu se tak transformovala do feudálního „ne-státu“. Před nástupnickými rody bývalého franského

Susan Reynoldsová [1997, 2003], která si dovolila Weberovu definici státu poněkud poupravit a mírně ji relativizovat. Podle jejího soudu mohou být státy lidské pospolitosti, jež si na určitém více či méně vymezeném území nárokují (či částečně nárokují) více či méně legitimní monopol na výkon fyzické moci, což je podle ní charakteristika platná pro většinu ze středověkých států. Přes tyto námitky vůči Weberově koncepci se jí v rámci naší statě přidržujeme, zejména poněvadž: za prvé, vychází z ní Eliasova koncepce; za druhé, umožňuje lépe pochopit přechod od post-antického $\mathrm{k}$ feudálnímu a od něj k post-feudálnímu státu; za třetí, lépe dokládá klíčové rozdíly mezi utvářením států ve stř̌ední Evropě a na Západě.

5 Zůstává samozřejmě otázkou, nakolik je takováto koncepce, naturální nebo také zemědělské ekonomiky, připomínající v mnohém Marxovu feudální výrobní formaci, platná pro veškeré oblasti Evropy. Obzvláště kdybychom přijali některé z argumentů americké socioložky Janet Abu-Lughodové [1989] o existenci dvou dílčích hospodářsko-tržních okruhů: tj. malých světových systémů, nalézajících se jednak v trojúhelníku mezi Troyes, Brugami, Gentem a Ženevou, a jednak ve Středozemí. Podobně budeme argumentovat i v prrípadě přemyslovského knížectví, jež se v 10. století vyznačovalo mnohými rysy, které ho od výhradně naturální ekonomiky poněkud odlišovaly. 
vladařského domu vyvstala obtížná situace, jelikož neměly dostatek zdrojů k tomu, aby byly schopné nad svým územím nastolit jednotný přinucující monopol, díky čemuž započal boj všech proti všem o kontrolu místních domén a oslabení nejbližších konkurentů. Tato rozsáhlá decentralizace, jež postihla západní Evropu, je podle Eliase zároveň př́íčinou ohromného konkurenčního zápasu z části vedeného o nadvládu nad prostorem bývalého Impéria, zčásti o pouhé přežití či alespoň udržení vlastní nezávislosti v těchto bojích, nebot’ se objevila všeobecná obava: „[... získá-li jeden ze sousedů na velikosti a síle, hrozí druhému sousedovi nebezpečí, že jím bude přemožen nebo se na něm stane závislým“ [tamtéž: 133].

Druhou příčinu, jak jsme již poznamenali, lze shledat ve vnitřních tlacích vyvolaných překotným demografickým nárưstem s počátkem v 11. století. ${ }^{6}$ Počet obyvatel tehdejší Evropy vzrostl natolik, že jej nebylo možné na dosavadní technologické úrovni uživit, a proto šlechtici museli začít rozšiřovat svá území. Elias v tomto kontextu píše: „[...] o znamení všeobecného hladu po zemi, který udržoval v napětí přibývající obyvatelstvo [...] po celé generace se kontinuální snaha ubírala přibližně stejným směrem - k akumulaci země [tamtéž: 133, 137, srov. též 141]. Chybějící půda podněcovala rytíre k ještě urputnějšímu soupeření, což bylo z velké části dáno také tím, že ekonomické zdroje, a tedy i hospodářskou moc ustanovovalo vlastnictví půdy. Pakliže chtěl rytír získat náležitou konkurenční výhodu před svými soky, musel se alespoň pokusit o rozšíření vlastního teritoria a zábor ještě neobsazené (anebo jiným sokem zabrané) půdy.

Tyto př́ićiny vyvolaly ve společnosti rozsáhlé vnitřní tenze a spustily mechanismus soupeření o moc - tzv. monopolní mechanismus. Jednotliví feudálové, jestliže se chtěli stát konkurenceschopnými ve střetech s vnějšími silami a uspokojit vnitřní síly prahnoucí po půdě, museli v prvé řadě navýšit svůj vlastní majetek. Právě proto se stala snaha o rozšíření vlastnictví půdy klíčovou sjednocující příčinou utváření států mezi 9. až 13. stoletím. Skrze tento postulát se také v Eliasově díle setkávají Marx s Weberem, nebot’ zisk ekonomických zdrojů (půdy) a zisk politické autority (mocenského monopolu) jde v tomto ohledu ruku v ruce: oba se vzájemně potřebují a umocňují. Čím více půdy šlechtic vlastní, tím více zdroji může disponovat, a tím spíše bude úspěšnější ve střetech s jinými velmoži a nakonec i tím pádem snáze uspokojí poptávku populace po půdě, díky čemuž bude disponovat více zdroji, atd.

\section{Monopolní mechanismus}

Souběh výše uvedených podnětů vyvolal komplexní systém soupeření o ustavení mocenského monopolu. Elias jím míní proces konkurenčních zápasů, během nichž dochází

6 Do té doby jej alespoň zasazují francouzští historici Marc Bloch a Georges Duby. Podle obou tento proces vyvolal tzv. středověkou mutaci (La mutation), skrze niž byly i ty poslední zbytky přežívajícího služebního systému post-antického státu nahrazeny nezávislými velkostatky, opírajícími se o moc pozemkových vlastníků, tj. šlechty. Tento stav byl pak definitivně zpečetěn výstavbou silně opevněných hradů, které jejich nově nabytou moc chránily před zásahy z vnějšku [Klápště 2009: 45-49]. Oba tedy podporují Eliasovu tezi o vlivu demografických trendů na decentralizaci státní struktury. Jiný historik, Massimo Livi Bacci [2003: 13], na jednom ze svých grafů velmi pěkným způsobem ilustruje kvantitativní charakter celého procesu. Evropská populace totiž od roku 1050 až zhruba do roku 1300 nepřestávala růst a zvětšila se z asi 50 milionů na 100 milionů obyvatel. Takováto kvantitativní proměna se samozřejmě neobešla bez zásadní dohry pro sociální strukturu a politickou organizaci. 
k postupné centralizaci moci v rukou jediného šlechtického rodu. Proces sociogeneze státu není tedy z velké části ničím jiným než eliminačním zápasem, procesem selekce, vyznačujícím se vyloučením poraženého rivala ze hry o moc. Charakteristickým znakem tohoto zápasu se stává stabilní vnější expanze. Osobnostní kvality jednotlivců a náhoda nehrají $\mathrm{v}$ celém procesu žádnou významnou roli, fungují pouze jako omezení, anebo nanejvýše zpomalení těchto procesů. $\mathrm{V}$ tomto ohledu se Elias také neliší od některých Marxových názorů na charakter sociální změny. Na jednom místě pak dokonce nazývá monopolní mechanismus zákonem, jehož základní premisa zní: „Společnost, s mnoha relativně stejně velkými mocenskými a vlastnickými jednotkami, má při silném konkurenčním tlaku tendenci ke zvětšování několika málo $\mathrm{z}$ nich a nakonec $\mathrm{k}$ vytvoření monopolního postavení [tamtéž: 114-115]. O něco dále svou definici rozvijí a zpřesňuje: „Lidské předivo, v němž si na základě velikosti mocenských prostředků vzájemně konkuruje relativně značný počet jednotek, má tendenci opouštět tuto rovnovážnou pozici a přiklánět se $\mathrm{k}$ jiné, v níž si vzájemně konkuruje stále méně jednotek. Jinak řečeno, blíží se $\mathrm{k}$ situaci, při níž jedna společenská jednotka dosáhne díky akumulaci monopolu nad žádoucími mocenskými šancemi“ [tamtéz:: 115]. Stav decentralizované sociální moci tak nabývá stále více svého opaku, stavu centralizovaného.

Konkrétní podoba monopolního mechanismu zahrnuje především jednotlivé střety šlechticů soupeřících o moc. Sociální aktéři se snaží rozhojnit svou vládu nad dalším a dalším územím, rozšíriit svůj majetek, a tím centralizovat mocenské zdroje. Proto jsou významnými součástmi formačních procesů jednotlivé sociální skupiny zapojené do monopolního mechanismu. Jmenovitě jde o čtyři skupiny aktérů: 1. panovníky, 2. šlechtu, 3. církev a 4. měštanstvo. Centrální konflikt mezi nimi se vede především po linii svárů mezi panovníky - kteří z počátku nepředstavují nic jiného než jen o něco silnější šlechtice přináležející k rodům s největším pozemkovým vlastnictvím - a zbylou šlechtou. Jelikož je však šlechta převyšuje početně, panovníci se spojují s dalšími aktéry, aby ji porazili, zvláště pak s církví a později, počínaje 13. stoletím, i s měštanstvem. Klér podle Eliase [2007: 188-190] doslova představoval vladařovu „pátou kolonu“ podrývající základy legitimity místní šlechty, kde to jen šlo, za což si však nárokoval na panovnickém stolci dlouhodobé zaštítění světskou autoritou. Prostřednictvím toho a třeba též skrze rozsáhlou participaci církve na správě veřejných (tj. panovnických) záležitostí se postupně formovalo úzké spojenectví trůnu a oltáře, spojenectví obzvláště typické pro mnohé z tehdejších států. ${ }^{7} \mathrm{O}$ něco později, jakmile Evropa prodělala jednu ze svých historicky prvních modernizací, začali panovníci v nemalém rozsahu využívat pro své potřeby i dalšího z uvedených aktérů, měštanstva, jež pro jejich pokladny znamenalo nenahraditelný zdroj finančních př́ijmů. Nicméně ani v tomto př́ípadě to nebylo zadarmo, nebot panovníci museli městům garantovat za jejich podporu důležitá práva a svobody, které jim v politickém předivu feudálního systému zajištovaly určitou samostatnost [Elias 2007: 142].

Jak staletí ubíhala, mocenské boje se postupně přesouvaly na stále vyšší rovinu obecnosti. Od dílčích zápasů mezi rytî́ri soupeřícími o autoritu nad místním územím, směrem ke střetům vlastníků panství, kteří zápolili o moc nad vévodstvími. Vévodové se pak snažili

7 Výjimku však tvořila sociogeneze Německa, kde stála církev proti státu a vždy spiše podporovala odstředivé než dostředivé tendence [Elias 2007: 119]. 
získat hegemonii nad hrabstvími, a nakonec ta nejúspěšnější hrabata soupeřila o nadvládu nad samotným královstvím. Aktéŕi tak byli stále - z principu celého procesu - nuceni usilovat o další rozšiřování svého monopolu. Snažili se expandovat, jinak jim hrozilo, že stanou v budoucnu mezi poraženými, čímž se dostávali pod stálý tlak. Ještě o něco později se podle Eliase tato hierarchie střetů měla transformovat do konfliktů mezi jednotlivými státy o kontrolu nad určitými nadstátními regiony, a ještě později dokonce v boj o světadíly [tamtéž: 111, 114].

Celý proces trval podle autora až do chvíle, kdy se vytvořily tak velké mocenské monopoly, že ty ostatní již nedisponovaly schopností je pohltit. Podoba mezinárodního systému, jak jej dnes známe, je tudíž výslednicí stabilizace jednotlivých expandujících monopolů, nacházejících se, byt’ třeba jen dočasně, ve vzájemném rovnovážném stavu.

\section{Determinanty monopolního mechanismu}

Přestože podle Eliase zůstává monopolní mechanismus univerzálně platný jako „zákon“, je třeba zmínit, že neprobíhá za všech okolností stejným způsobem (především ve smyslu rychlosti ustanovování velkých státních monopolů), ale jeho konkrétní průběh se značně různí s měnícími se zeměpisnými podmínkami. Ty jsou ostatně rovněž jeho hlavní determinantou. Topografie terénu, jeho členitost i celková rozloha území, o nějž vedou soupeř́ící strany boj, naprosto rozhodujícím způsobem ovlivňují intenzitu a souvislost centralizačních tendencí. Př́liš velká území s rozmanitými krajinnými rozdíly, a tudíž častokrát také se značnou společenskou diverzitou, mohla samotné centralizační působení značně omezovat, ne-li jej úplně hatit a působit proti němu. Tyto rozdíly dodávaly lokálním odstředivým tendencím patřičnou sílu, což znesnadňovalo veškeré pokusy o centralizaci moci. Taktéž prŕliš velké říše se často štěpily, obvykle po svém obvodu, kde byly vystavovány štěpícím procesům tak dlouho, než dosáhly velikosti, kterou by bylo možné za stávající situace udržet. ${ }^{8}$ Takovýto stav byl způsoben například také tím, že tehdejší

8 Joseph Strayer [1971: 346-347], ale i jiní autoři [Tilly 1975: 42, 49; Rokkan 1975: 577, 582], v tomto kontextu rozlišují dva typy států: 1 . Jednotné státy, disponující již v brzkých dobách značnou homogenitou; 2. Mozaikové státy, mající naopak vysokou heterogenitu. Jednoznačným reprezentantem prvého typu byla Anglie, rysy druhé formy se naopak vyznačovalo Německo. Tam, kde stát připomínal spíše politickomocenskou mozaiku, byla jeho unifikace pro vladaře mnohonásobně náročnější a nezřídka k ní vůbec nedošlo.

K velmi zajímavému pohledu na některé z teorémů nabízených koncepcí monopolního mechanismu se můžeme dobrat skrze práci historika Roberta Bartletta [1994: kap. 2] o utváření Evropy během let 950 až 1350 . Autor se ve své oceňované knize pozastavuje nad problémem tzv. „aristokratické diaspory“, která zasáhla šlechtické rody během vrcholného středověku. Mnoho z tehdejších šlechticů, obzvláště druhorozených a mladších synů vážených rodin, bylo díky zmenšujícím se šancím na zisk vlastního léna s řádným renomé nuceno opustit svá rodná panství a hledat štěstí někde jinde. To znamenalo vydat se na trnitou cestu kolonizace odlehlých periferních území. Tu si zvolila podstatná část bývalé franské šlechty, začínající osídlovat rozsáhlé prostory Pomořanska, ale totéž platilo i pro normanské pronikání na Sicílii, Britské ostrovy a dále do Walesu, Skotska a Irska. V neposlední řadě byly tyto snahy podstatné také pro zakládání křižáckých státečků ve Stř̌edomoří a v Levantě.

Tímto krátkým poukazem na Bartlettovu studii chceme naznačit přinejmenším tři podstatné věci: za prvé, formování států nebylo (nemuselo vždy být) sebe-stravovacím (monopolním) mechanismem veškeré evropské šlechty, která z něj neměla kam uniknout. Vedle něj po jistou dobu velmi dobře fungoval jiný mechanismus, přinejmenším stejně významný, který umožňoval zakládat nové politické jednotky bez přispění krvavých vylučovacích zápasů., ačkoli to neznamená, že by k migraci a následné kolonizaci docházelo výlučně nenásilnou cestou. Za druhé, rychlost centralizace (intenzita působení monopolního mechanismu) byla striktně závislá na možnostech migrace určité části šlechty. Tam, kde jí byla umožněna, byly centralizační procesy mnohem 
vladaři nedisponovali po dlouhé časové období dostatečnými zdroji, jimiž by byli schopni zabezpečit svou nadvládu alespoň nad místní konkurencí; ve středověku nebylo nikdy úplně možné překonat odstředivé tendence [tamtéž: 111-112, 116]. Z tohoto důvodu byly centralizační procesy velmi pomalé a koncentrické tendence byly vždy doplňovány těmi excentrickými. Právě různorodé zeměpisné podmínky proměňovaly všeobecné působení monopolního mechanismu v celé Evropě, díky čemuž se Francie a Anglie zcentralizovaly do podoby států mnohem rychleji, než tomu bylo v prŕípadě Německa, kde se podle Eliase př́roda postavila proti sjednocujícím tendencím.

\section{Důsledky monopolního mechanismu}

Konečným dopadem formačních procesů 9. až 13. století bylo podle Eliase vytvoření základů prvních centralizovaných královských monopolů, prvních dnes známých evropských státních celků, byt tento proces pokračoval i v dalších staletích a v západní Evropě vygradoval o sto let později. Nicméně již v této době bylo možné postřehnout důležité překonání původně odstředivých sil, které vyvolala destabilizace post-antického státu v podobě rozpadu Karolinské říše. K tomu došlo, poněvadž již byla většina půdy, jenž byla původně k mání, přerozdělena mezi hlavní politické aktéry tehdejšího světa. Panovníkům se v sérii zápasů trvajících po několik století - vedených jak mezi sebou navzájem, tak s relativně autonomní šlechtou - podařilo vytvořit takový druh společenského uspořádání, v němž se stali centrální, i když do určité míry stále okleštěnou politickou silou. Tam, kde si šlechta nadále udržela značnou autonomii na královské Koruně, spěl stát spíše ke stavovskému uspořádání, kdežto v místech, kde se začala tato nezávislost vytrácet, se pomalu rýsovaly první vzdálené kontury absolutistických režimů. Za důležité považujme v rámci této debaty zvláště to, že došlo k přechodu od feudálního „ne-státu“ ke státu, jenž již disponuje mnohými aspekty definice Maxe Webera: je to totiž stát, v němž panovníci, prozatím alespoň formálně, drží monopol na legitimní užití fyzické síly. Tento monopol se díky eliminační soutěži nalézá v jejich rukou, čímž také končí éra soukromých mocenských střetů a ty od této chvíle spadají mezi veřejné záležitosti. $\mathrm{V}$ rámci celého procesu bychom pak měli na závěr podtrhnout dva významné momenty. Tím prvním je ustanovování monopolu ve vztahu k populaci státu, respektive ve vztahu k politickým aktérům na území státu, který inklinuje k převaze panovníků nad šlechtou. Vladaři - a jejich prostřednictvím i stát - se stávají hlavními aktéry mocenské politiky dalších století. Druhý moment představuje budování monopolu ve vztahu k jiným monopolům, tj. ve vztahu k vnějšímu prostředí států, které je spojeno s profilací evropského mezistátního systému. Státy se tak pomalu stávají ústřední složkou, nikoliv však stále jedinou, evropské makropolitiky.

pomalejší, nebot’ aristokracii zajištovaly zisk zdrojů bez nebezpečí fatální konfrontace ve smyslu „kdo z koho“. Tam, kde jí byly po určitém čase možnosti mocenské mobility zahrazeny, se naopak intenzita soupeření mezi jednotlivými šlechtickými rody značně zostřovala. Za třetí, uvedené procesy se netýkaly pouze nižší šlechty, ale byly do nich zapojeny i panovnické rody. Mnoho z královských dynastií vrcholného středověku totiž pocházelo ze zahraničních rodů, nikoliv z vítězů střetů mezi domácím panstvem. Bartlett [1994: 39nn] v tomto kontextu dokonce píše o dynastické difúzi, která měla zasáhnout Kastilii, Soluň, Portugalsko, Kypr, ale kupříkladu i Čechy, kde nastoupili na trůn Lucemburkové. Není pak jistě bez zajímavosti, že až osmdesát procent těchto rodů mělo své původní državy na území dnešní Francie a bylo více či méně pokrevně spřízněno s kapetovskou dynastií. 


\section{Sociogeneze v západní Evropě}

Norbert Elias ukazuje principy fungování své teorie na empirických příkladech celkově tří zemí: Francie, Anglie a Německa, přičemž prvně jmenovaná země jeho výzkumům jasně vévodí. Na tomto místě se však nechceme v prvé řadě věnovat tomu, nakolik je autorův popis tamních formačních procesů adekvátní empirické realitě, nýbrž se hodláme spíše zaměřit na obecné tendence $\mathrm{v}$ utváření státních organizací $\mathrm{v}$ téže oblasti, a to tak abychom je mohli srovnat s procesy, jež probíhaly na území Čech. Z tohoto důvodu v dalších odstavcích uvádíme, jak působil monopolní mechanismus na utváření anglického a francouzského státu v období zhruba od poloviny 9. až do konce 13. století. Obě země pak zároveň bereme, obzvláště Francii, za hlavní reprezentanty utváření státu v západním cípu evropského světadílu. Kromě toho je pak do našich analýz zařazujeme z ještě jednoho důvodu. Elias [2007: 141-142] se totiž domnívá, že můžeme na zdejší utváření států nazírat jakožto na konstituci dvou proti sobě stojících monopolů, jednoho kontinentálního, pozdější francouzské domény, a jednoho ostrovního, základny budoucího anglického státu. Jejich utváření tedy bylo vzájemně propojeno.

Raně středověká Anglie bojovala dlouho o své bytí a nebytí se zahraničními nájezdníky, především Dány, kteří až do nástupu Alfréda Velikého k moci ovládali podstatnou část ostrovního území. K tomu všemu se zde nacházela též četná nezávislá etnika, zvláště v periferních oblastech, kde žili Skotové a Walesané, ale po jistou dobu se určité autonomii těšil třeba i takový Cornwall. Mezi řadou drobných mocenských monopolů zde tak již od počátků probíhal jeden ozbrojený stř̌et za druhým, z nichž nejpodstatnějším se nakonec stala anglosaská revolta vůči vikingským okupantům, kteří ovládali velkou část stř̌edovýchodní Anglie, tzv. Danelaw. Série válek - rozhořivší se mezi dánskými nájezdníky a anglosaskými kmeny, jimž nezbývalo nic jiného než se přes vzájemné půtky spojit pod vedením již zmiňovaného Alfréda a utvořit jednotný mocenský monopol schopný čelit tomu dánskému - nakonec přivedla Anglii k mnohem unifikovanější podobě, než tomu bylo o století dříve. Základní politické scelení stř̌edověkého státu pak dokončil Alfrédův syn Edward, jenž roku 937 dospěl až k říčce Humber na severu, oddělující anglické území od toho skotského. Toho se však nebyli Angličané ještě po nějaký čas schopní zmocnit. Další důležitý zásah do zdejšího formování představovala normanská invaze z roku 1066, která přivedla na trůn novou panovnickou dynastii v čele s Vilémem Dobyvatelem, nastolujícím jeden z prvních evropských „primitivních absolutismư “ (výraz převzatý od Perryho Andersona [1974]). Vilémova dynastie tak nerozlučně propojila místní vývoj s tím, jenž se mezitím odehrával na pevnině. Normanský zábor je $\mathrm{z}$ našeho úhlu pohledu důležitý přinejmenším ze dvou důvodů: dílem totiž představoval výměnu mocenský elit v rámci stávajícího královského monopolu, tedy významný transfer moci v politě (v politické sféře), jednak znamenal celkové rozšiřrení královské domény východním směrem, za kanál La Manche, a tím i nové pojetí anglické zahraniční politiky, nucené od nynějška vyvažovat zájmy ostrovní a pevninské. Jednalo se tak o zájmy, které se měly v budoucnu projevit četnými odstředivými tendencemi na domácí půdě, jak tomu bylo například za vlády Jana Bezzemka.

Události, jež doprovázely profilování Francie, měly velmi podobný spád jako v př́padě Anglie. Podle Eliase [2007: 112] zde docházelo k soustavné integraci mnoha malých regionů v rukou nejsilnějších rodů a později i samotného krále. ${ }^{9}$ Navíc tato integrace probí-

9 Obsáhlejší a v mnoha aspektech propracovanější popis tohoto procesu na příkladu Francie nabízí Duby [2003, 2008]. 
hala relativně kontinuálně, jen s občasnými přerušeními vyvolanými střety s nejsilnějšími aristokratickými rody. Pro postupný kumulativní vývoj státních institucí se zde nacházely dobré podmínky, takže stát rostl od malého k většímu. To se projevovalo pozvolným, byt zprvu nenápadným zvětšováním rozlohy královské domény, rozkládající se původně okolo oblasti Ill-de-France, na další a další kraje. Naprosto rozhodujícím byl v tomto rozpínání, vedoucím do různých směrů, okamžik, kdy se oba monopoly - francouzský i anglický - počínaje 12. stoletím střetly při soupeření o bývalé normanské provincie na západním pobřeží Francie, tj. o oblast Anjou. Toto vzájemné zápolení se pak stalo jejich raison d'être a hybnou silou utváření až do konce Stoleté války, jíž tento vzájemný zápas vygradoval, a obě země se ustálily v přibližně těch hranicích, které známe dnes. Jinými slovy takových, jež dokázaly při tehdejším způsobu získávání zdrojů pro vedení války udržet.

V př́padě obou zemí tak můžeme sledovat, že jejich vývojové tendence odpovídají Eliasově teorii, nebot proces centralizace státní moci probíhá, i když s některými výkyvy, soustředným směrem a vede: za prvé, k navyšování koncentrace legitimního přinucení v rukou panovníků na úkor jiných politických subjektů. Za druhé, rozšiřuje se rozloha území, nad nímž je tento monopol vykonáván, a to tak dlouho, dokud se oba rostoucí monopoly nestřretnout a nemohou expandovat dále, jelikož se nejsou schopny vzájemně pohltit. Původně nezávislá šlechta je také postupně stále více stravována eliminačními zápasy, upadá do závislosti na panovnické Koruně a je mnohem více, různými postupy, integrována do státních organizačních struktur; nezvratně se z ní stává součást ústrojenství státu, jehož organizační principy se blíží tomu, co Max Weber nazýval patrimoniální správou. Ze šlechtice válečníka se začíná pomalu stávat šlechtic úředník zaměňující svůj meč za pero a kalamář, tedy jedinec, pro něhož vavříny ze soubojových kolbišt začnou postrádat smysl a který na místo toho bude usilovat o ostruhy za službu ve státní správě. Ta se totiž stává novým garantem jeho statusu.

Hlavní rozdíly v sociogenezi obou zemí přitom zpo̊sobily zeměpisné faktory. Anglie, jelikož byla mnohem menší, byla také mnohem rychleji sjednocena než království Kapetovců. Centralizační procesy, respektive střety, které je doprovázely, zde byly díky menší rozloze území od počátku nevyhnutelné, a tudíž i mnohonásobně urychlenější, než tomu bylo v prŕpadě Francie se čtyřnásobnou velikostí. Rychlosti formování plantagenetovské domény nahrávala také přirozená ohraničenost Anglie coby ostrova. Ta jí zaručovala i přes všechny obtíže, jimž musela nezřídka čelit ve svých provinciích na pevnině - že odstředivé tendence nikdy nepřekročí tu míru, jež by znamenala výraznou vnitřní destabilizaci [Elias 2007: 117-119]. Situace kapetovských vladařů byla díky rozloze a členitosti francouzského území složitější, protože vnitřní politické turbulence, pưsobící jako odstředivé síly, znesnadňovaly, a tudíž prodlužovaly dobu ustanovování panovnického monopolu. Zatímco anglické formování bylo mnohem lineárnější, to francouzské probíhalo spíše neobratným rytmem dva kroky kupředu a jeden kroku vzad. Průběh formování konkrétních států tedy není v Eliasově podání nikdy úplně přímý. Nepředstavuje pozvolnou kontinuální gradaci mocenského monopolu, ale spíše neustálé pulzování integračních a dezintegračních mechanismů, které až z pohledu času velmi dlouhého trvání budí dojem postupné a nezadržitelné centralizace. ${ }^{10}$

10 Jiř́ Šubrt [1996, 2007] nazývá tyto oscilace dostředivými a odstředivými tendencemi. S podobnou teorií jako Elias ovšem koncem šedesátých let přišel i sociolog polského původu Stanislaw Andreski [1968: 75-78], jenž 


\section{Sociogeneze přemyslovského knížectví}

Zatímco v půli 9. století se na západě hroutil jeden z posledních nositelů tradice antické sociálněpolitické organizace, Karolinská ř́še, na východě byla situace naprosto odlišná. Zde státy teprve vznikaly a čekaly na svou dějinnou př́ležitost. Toto prosté konstatování zároveň představuje nejpodstatnější z rozdílů, z něhož pramení i většina dílčích odlišností mezi zdejší sociogenezí a utvářením států v jiných oblastech. Prostředí dlouhodobě „znalé státu“ a prostředí dlouhodobě „bezstátni“ totiž produkují zcela rozdílné formační trajektorie. Česká kotlina, situovaná po léta za hranicí dosavadního civilizovaného světa, vně bývalého Limes Romanum, tak disponovala jinými východisky než ta část Evropy, o niž projevuje Elias největší zájem. Samozřejmě že v roce 860 , kdy začínáme naši analýzu, není již české knížectví kmenovou strukturou, jakou byl z velké části ještě Sámův kmenový svaz, ale je státem, byt’ v tomto okamžiku stále jen coby poloautonomní součást Velké Moravy [Charvát 2007; Třeštík 2001; Žemlička 2002a]. Abychom tudíž lépe pochopili genezi přemyslovského knížectví, musíme se na moment zastavit u jeho vztahu k Velkomoravské říši, který byl pro další vývoj této politické domény v mnoha ohledech určující.

Velkomoravská říše, vzniknuvší z části díky kulturní inspiraci Franskou říší a z části $\mathrm{z}$ odporu vůči avarskému kaganátu, ovládala rozsáhlou oblast střední Evropy a jako jedna z prvních si zde také vytvořila rozvinutou státní strukturu. Tou je míněno centrální řízení především vojenskopolitických záležitostí, které bylo v regionu, jež byl oblíbeným terčem jak kočujících nájezdníků z panonské nížiny, tak franských loupeživých výprav, otázkou přežití. Stát zde tudíž vzniknul z nutnosti zachování pozice stávajících politických elit. V tom se tedy tato situace příliš neliší od názoru švýcarského klasika dějepisectví 19. století Jacoba Burckhardta [1971 (1905): 29] o původu států. Pro výkon jeho moci byla zavedena soustava opěrných bodů, tzv. hradská soustava, v níž se shromaždoval hospodářský nadprodukt (zvláště oděvy sloužící vojákům). Velkomoravský stát však nebyl státem ledajakým. Jelikož vzniknul z války, válka se stala jeho průvodní, životadárnou aktivitou. Jedinou možností jak přežít v nestálém makropolitickém systému střední Evropy bylo vlastnit velké a bojeschopné vojsko a jedinou možností, jak tuto sílu uživit, se staly nájezdy. Pokud se tedy snažíme definovat základní rysy velkomoravského státu, musíme se uchýlit k termínům vojenský a kořistnický. Vojenský proto, že jeho základem se stala armáda zaštitující mu legitimitu, kořistnickým proto, poněvadž nejsnazším způsobem, jak získat pro jeho ozbrojené složky zdroje, bylo kořistění. Mezi náklady na vojsko a existencí státu tak existoval provázaný dialektický vztah, jedno si vždy vyžadovalo druhé. Velká Morava dokázala tomuto napětí unikat jen z jednoho prostého důvodu, profitovala totiž z obchodu s otroky, nejvýznamnějším obchodním artiklem oné doby, které získávala skrze své výboje. Z Čechů a Moravanů, do té doby častého cíle zahraničích nájezdníků, se tak stávali sami organizovaní nájezdníci. Právě na obchodu s otroky založená státní ekonomika, na níž

se domníval, že každá politická struktura v sobě inherentně obsahuje jak koncentrické, tak centrifugální síly, které ji bud' štěpí, anebo sjednocují. Za dlouhodobou fluktuací těchto sil je podle něj skryta povaha vojenské taktiky a technologie. Pokud obě vedou k převaze útoku nad obranou, dochází ke koncentraci politické moci v rukou jen několika málo subjektů (případně státu), zatímco když obrana začne hrát prim, triumfují decentralizační síly. Konečný triumf ofenzívy nad defenzívou směřuje i k vymizení nezávislých center moci v rámci dané územní jednotky, či alespoň k těsnějšímu upevnění vlády nad celou oblastí. Převaha obrany pak dává vzniknout přesně opačným konsekvencím. 
měla velkomoravská knížata faktický monopol, zabezpečovala finance, které udržovaly státní aparát v chodu [Galuška 2003; Havlík 1992: 129; Třeštík 2001, 2008: kap. 14, 2009; Žemlička 2002a: 40].

Území pod vládou přemyslovských knížat se za takových podmínek stalo rychle součástí velkomoravské správy, čímž došlo k významné difúzi institucí zajištujících regulaci sociálního života z Velké Moravy do české kotliny. ${ }^{11}$ Když se pak koncem 9. století dostala říše Moravanů do krize způsobené náporem mad’arských kmenů, Přemyslovci již disponovali receptem na to, jak v nově vzniklém mocenském vakuu vystavět svůj vlastní stát. Pád Velké Moravy tedy nevedl, oproti procesům na Západě, k rozkladu mocenských struktur a ke vzniku feudálního „ne-státu“, nýbrž vyústil v ustanovení základů přemyslovského státního monopolu, se všemi znaky kořistnického a vojenského státu předcházejícího období. Paradoxně, jak dokládají výzkumy českých historiků [Třeštík 1987, 2006, 2008: 294nn, 2009: 83nn; Žemlička 2002a: 153nn, 2009: 166nn], připomínal tento typ státní organizace weberovský vzor více než jakýkoliv jiný tehdejší státní útvar: disponoval legitimním monopolem na násilí, územím, na němž bylo zmíněné přinucení praktikováno, a dokonce i centralizovanou správou zodpovědnou za výběr daní a provádění státních nařízení. Český stát, vznikající na troskách Velké Moravy, tak disponoval zcela odlišnými charakteristikami než Eliasem popisované západoevropské politické režimy. Centralizovaný mocenský monopol, byt̉ nepř́liš geograficky rozsáhlý, totiž už dávno měl, díky čemuž byla povaha jeho dalšího utváření zcela jiná než ta, kterou ve své teorii popisuje Norbert Elias. Pakliže bychom danou myšlenku ještě o něco dále rozvedli, mohli bychom uvést, že stát, k jehož konstrukci mělo na Západě dojít někdy okolo 14. až 15. století, zde existoval ve své esenciální podobě už o pět století dříve. V tomto kontextu samozřejmě zůstává nevyslovenou otázkou, zdali takovýto stát nalézající se na periferii vyrůstá na základě zahraničních inspirací, častokrát doprovázených odtržením místodržitelské elity, nebo vzniká zdola, jako pokus ochránit stávající, tj. domácí, elity před vnějším tlakem.

Na dalších řádcích se budeme věnovat zkoumání toho, jak se raný mocenský monopol vyvíjel od přelomu 9. a 10. století až do roku 1230, přičemž se zaměříme na dvě vzájemně propojené oblasti: z části budeme sledovat to, sledovat zpơsob, jakým docházelo $\mathrm{k}$ proměně jeho teritoriální moci, jak expandoval, nebo se naopak smrštoval na úkor jiných monopolů, z části budeme pozorovat to, co se dělo s ním samým, tj. s centralizovanou administrativní a vojenskou strukturou, jíž disponoval. V rámci takto naznačené výzkumné dráhy budeme postupovat po stejných bodech, jako tomu bylo v př́padě Eliasovy teorie. To znamená, že nejdříve upozorníme na předpoklady a příčiny zdejší sociogeneze, poté obrátíme svou pozornost k samotnému monopolnímu mechanismu, včetně jeho hlavních aktérů, a nakonec shrneme nejvýznamnější důsledky jeho dynamiky.

11 Tento scénář samozřejmě není jediným možným a lze ohledně něj vést určité dohady, nebot mohli: 1 . být do struktur velkomoravské správy integrovány jen některé české kmeny; 2. Přemyslovci mohli mít také již před tímto začleněním vytvořenu vlastní více či méně rozvinutou „státní“ organizaci, která pak byla následně integrována do té velkomoravské; 3. přemyslovské panství si udrželo jistou úroveň autonomie a bylo spíše formálně nežli fakticky začleněno do správy Moravanů; 4. mohlo dojít ke kombinaci a postupné fúzi všech tří zmíněných eventualit. Pro zcela exaktní tvrzení o tom, co se přesně událo, však česká archeologie a historiografie doposud postrádá dostatek důkazů. 


\section{Příčiny a předpoklady sociogeneze přemyslovského knížectví}

Prvotní podmínku zdejších formačních procesů, rozumějme přemyslovského knížectví, jsme si stačili představit již v prologu věnovaném Velké Moravě. Ustanovení českého knížecího monopolu bylo tedy spojeno s politickou destabilizací, a to dílem Velkomoravské říše a dalším dílem pak $\mathrm{k}$ němu jistě přispělo i relativní oslabení Východofranské domény, nedosahující zdaleka takové síly, jíž se těšila v éře Merovejců. Rozklad a oslabení okolních mocenských monopolů tak dal Přemyslovcům jistou strukturální výhodu, jež jim umožnila položit základy vlastního státu. ${ }^{12}$ Drobný časový náskok, který díky tomu pro sebe získali, jim pomohl udržet si i v sousedství tak silného státního útvaru, jakým byla německá ř́íše, určitou samostatnost. ${ }^{13}$ Přesto byla politika českých knížat ve vztahu k Říši vždy úzce spojena, a to sice nejenom skrze odvádění tributu západnímu sousedovi a vlivem christianizace, nýbrž i prostřednictvím vyvažování sil ve středoevropském regionu, jak upozorníme o něco dále. Druhou podmínku sociogeneze jsme též stačili v určitých obrysech naznačit a týká se prvopočátečního vývoje v rámci Velké Moravy. Nejde nám však o difúzi organizačních rámců, o níž jsme již výše diskutovali, ale o ochranu, kterou svou existencí stát velkomoravských knížat propůjčoval Přemyslovcům. Díky tomu, že byla česká knížata, alespoň v počátcích, součástí Velké Moravy, vyhnula se pohlcení ze strany říšského monopolu, stejně tak jako byla uchráněna před ničivými útoky mad’arských jízdních lučištníků. Brzké začlenění do velkomoravských struktur tak představovalo druhou strukturální výhodu českého státu, nebot ji chránilo, jako velmi účinný štít, před okolními, v té době výrazněji silnějšími mocenskými tělesy, jež by jej za jiných okolností pravděpodobně pohltily či vyvrátily.

Když dosud zmíněné shrneme, dospějeme k závěru, že raný český stát disponoval „hybridní“ výhodou periferie, jinými slovy pozicí, která se sice nacházela za hranicí oddělující barbarskou a nebarbarskou Evropu, ovšem která díky tomu zároveň mohla - za stávajících politicko-technologických podmínek - odolávat všem pokusům o obsazení ze strany některé ze silných západních říší. Přestože zdejší knížectví disponovalo v počátcích jen dílčí autonomií (nebylo faktickým monopolem), z dlouhodobého hlediska nebyl tento stav vůbec nevýhodný, nebot mu umožňoval obklopit se nárazníkovým pásem proti silnějším aktérům. Jakmile pak stávající nebezpečí z části polevilo a dále pak rozvrátilo původní politickoorganizační rámce, naskytla se Přemyslovcům mimořádná př́ležitost zbudovat svůj vlastní stát, stát o to silnější, že byl v daném okamžiku obklopen ze tř́i světových stran jen víceméně kmenovými organizacemi, které pro něj nepředstavovaly významné soupeře.

12 Dodejme, že tyto základy nebyly položeny na zelené louce, nýbrž vycházely z původní kmenové organizace zdejších slovanských kmenů, pro které existovaly určité předpoklady: rozvinutá sociální diferenciace a základní společenská hierarchie. Z jistého uhlu pohledu tak lze předpokládat, že působení Velké Moravy či inspirace ze strany Franské říše zde sehrály úlohu jakéhosi urychlovače již rozběhnutých (prvotních) centralizačních tendencí, které mírily k ustanovení „protostátu“ v tom smyslu, jak o něm obvykle uvažují političtí antropologové [viz Balandier 2000 (1967): kap. 6].

13 S podobnou úvahou přišel v nedávné době Stanislav Holubec [2009: 156nn], který tvrdí, že v oblasti Čech 6. až 9. století existoval malý světový systém v podobném smyslu, v jakém o něm uvažují Christopher Chasse-Dunn a Thomas D. Hall [viz tamtéž: kap. 12]. Díky jeho existenci se zdejším etnikům podařilo udržet při pozdějším začlenění do mocenských struktur křestanského západního světa samostatnost, což o jiných etnicích, například polabských Slovanech, říci nemůžeme. Pro platnost této koncepce pak svědčí i archeologické nálezy z poslední doby, které kromě obchodu s otroky dokládají také existenci čtyřstranného dálkového obchodu s jinou typicky českou komoditou, granáty [viz Charvát 2007: 54nn]. 
Tato naše zjištění se tedy v otázce počátků a podmínek formačních procesů poněkud rozcházejí se závěry Eliasovými. To platí mimo jiné i pro demografické procesy, jež v této oblasti nesehrávaly tak významnou roli jako na Západè.

\section{Přemyslovský knížecí mechanismus, aneb od centralizace k decentralizaci}

$\mathrm{Na}$ rozdíl do toho, co Elias popisuje jakožto klíčové principy sociogeneze, český monopolní mechanismus se vyznačoval přesně opačnou dynamikou. Byl pro něj sice rovněž typický sled konkurenčních zápasů, během nichž však nedocházelo v tak velké míře k postupné centralizaci moci v rukou jediného šlechtického rodu, nýbrž spíše k její decentralizaci a následnému rozmělnění mezi početné zástupce aristokracie, představujícími do té doby jednu z výkonných složek státu (patrimoniální úřednictvo). ${ }^{14}$ Nemáme zde tudíž co do činění s eliminačními zápasy a procesy selekce, jako spíše s postupnou privatizací státní moci, nabírající na obrátkách od poloviny 12. století. Z pohledu weberovské sociologie politiky bylo tedy hlavním principem místních politických svárů zápolení o přerozdělení vlivu a podílu na moci uvnitř státu, v rámci centralizované panovnické domény, a nikoli její budování. Hlavní problém panovníků proto nepředstavovalo rozšiřování státního monopolu, ačkoliv i to hrálo svou významnou roli, nýbrž obrana vůči různým vyzývatelům vznášejícím na zdejší knížecí stolec své požadavky. Obvykle přitom šlo o vyzývatele z řad zahraničních panovníků, zvláště těch německých, nehledě na uchazeče z řad knížecího rodu, kteří si nárokovali na panovnický post větší právo než jejich vládnoucí příbuzní. Teprve až v závěru námi sledovaného období se k těmto vyzývatelům přidala i postupně se emancipující patrimoniální šlechta, a v některých ohledech též církev. Přemyslovský monopolní mechanismus tak na jednu stranu vyvažoval pozici zdejších vládců vůči vnějším silám, na stranu druhou musel čelit týmž požadavkům ze strany domácí opozice. $Z$ tohoto úhlu pohledu tedy sledované místní procesy připomínají spíše jiný Eliasův koncept, tzv. královský mechanismus, jenž však bude podle něj charakteristický až pro centralizovaný stát 15. až 18. století. To však není nijak překvapující, jelikož v kvalitativních ohledech (nikoli kvantitativních) právě tento typ politické organizace tehdejší český stát připomínal. Kdybychom tedy chtěli v návaznosti na Eliase místní politickou dynamiku nějakým způsobem pojmenovat, asi nejvhodnějším termínem by zřejmě byl jakýsi knížecí mechanismus vyjadřující spřízněnost s právě jmenovaným královským mechanismem.

Jelikož podle Eliase konkrétní podoba monopolního mechanismu zahrnuje především jednotlivé střety aktérů soupeřících o moc, musíme se podrobněji zastavit u jejich základních aspektů a vzájemných vztahů. Zatímco v Eliasově teorii figurují čtyři principiální aktéři monopolního mechanismu, tj. 1. panovníci, 2. šlechta, 3. církev a 4. měštané, jejichž

\footnotetext{
14 Nejsme si samozřejmě úplně jisti, jak v tomto ohledu - při relativně skrovném historickém materiálu - komentovat střety přemyslovských držitelů moci s Lučany, Zličany, Slavníkovci a Vršovci. Zdali tedy máme tyto rody a jejich panství považovat za autonomní síly, které byly na přemyslovské moci nezávislé či téměř nezávislé, anebo je máme spíše chápat jako patrimoniální složky správy, jež v rámci ní vytvářela různé politické kliky a bloky, které knížecí vládě házely „klacky pod nohy“. V tomto textu se přikláníme k druhé eventualitě, nicméně, $\mathrm{z}$ omezených prostorových důvodů, jí nemůžeme věnovat větší pozornost než prostřednictvím této poznámky. Samožrejmě že další výzkum v dané oblasti se musí zaměřit i na principy závislosti a nezávislosti, potažmo kontroly a svrchovanosti, jednotlivých členů polity (a státního aparátu) v raně středověkém státě. Velmi inspirativními jsou pro takovýto typ projektu některé stati Edgara Kisera a jeho kolegů [Kiser, Drass, Brustein 1995; Kiser, Baer 2005].
} 
vzájemné spojenectví a nepřátelství utvářejí osy formačních procesů, skladba klíčových aktérů mocenského soupeření v přemyslovské knížecí doméně je jiná. Její součástí jsou také 1. panovníci, nicméně k nim musíme ještě přičíst 2. zahraniční vladaře (vnější mocenské vyzývatele), 3. vyzývatele z řad vládnoucího rodu a 4. domácí patrimoniální šlechtu. Církev a měštanstvo zde hrají, tedy v éře 860 až 1230 , mnohem menší roli. ${ }^{15}$ Zatímco panovníci jsou vlastníky většiny veřejných statků (například půdy, hradišt, zbraní aj.), šlechta není šlechtou v běžně užívaném slova smyslu - tzn. že by disponovala vlastními rozsáhlými velkostatky a byla by na panovnické moci nezávislá - ale představuje služebný stav, který pobírá za svou práci důchod, tj. podíl z vybraných daní. Patrimoniální šlechta tudíž není panovníkovým ústředním protivníkem, jak soudí Elias, nýbrž spojencem, byt’ i to se mělo časem změnit. Koalice panovníků a patrimoniální šlechty, jinak řečeno stát, tak stála proti vnějším i vnitřním vyzývatelů. Vnější vyzývatelé pak mohli sehrávat v případě přemyslovské domény natolik významnou úlohu pouze proto, že tehdejší český stát, jak už jsme v úvodu statě uvedli, nedisponoval úplnou mezinárodní samostatností. Tu si posléze definitivně vydobyl a potvrdil až za vlády Přemysla Otakara I. Ačkoliv ani tehdy, díky přetrvávání struktur Svaté říše římské, se nejednalo o samostatnost zcela neproblematickou. Tím pádem mohli zahraniční vladaři zpochybňovat legitimitu zdejších panovníků a pokoušet se o transfer moci v rámci státního monopolu, at už na svou vlastní stranu, nebo na stranu svých př́ívrženců (terminologií Jana Kellera [např. 2009: kap. 2] „klientů“). Posledním $\mathrm{z}$ významných konfliktních elementů byli uchazeči o vladařský post $\mathrm{z}$ přemyslovského rodu, kteří se někdy snažili na svou stranu získat šlechtu a jindy zase zahraniční panovníky. Ze spleti spojenectví mezi těmito čtyřmi typy aktérů následně vystupovaly kontury zápasu o moc, v němž se chtěl každých ze zapojených chopit vlády (popř́padě si ji udržet, či alespoň zlepšit své vlastní postavení uvnitř státu). Ve vývoji tohoto konfliktu pak můžeme zaznamenat dvě důležité fáze: první, spadající mezi 10. až polovinu 12. století, kdy hrály prim střety státu s vnitřními a zahraničními vyzývateli, a druhou, pro kterou byla naopak typická emancipace šlechty a postupná privatizace státní moci. $Z$ nejvěrnějších spojenců státu se tak zanedlouho měli stát jeho nejzarytější odpůrci. Tento zlom, k němuž $\mathrm{v}$ charakteru přemyslovského monopolního mechanismu došlo, byl spojen s přinejmenším trojicí vzájemně provázaných vlivů: 1. proměnou ekonomické základny státu; 2 . vzestupem dalších státních monopolů ve střední Evropě; 3. posílením patrimoniální šlechty díky tlaku vnitřních a vnějších vyzývatelů na knížecí trůn. Všem třem právě zmíněným aspektům se budeme nyní podrobněji věnovat.

1. Proměna hospodářství. Knížectví prvních Přemyslovců adaptovalo shodné mechanismy výstavby a udržování chodu státu, jaké předtím nalezneme na Velké Moravě. Stalo se tedy již od počátků loupeživým státem, žijícím především z lovu a prodeje otroků. Právě obchod s nimi, jenž měl centrum v rychle rostoucí Praze, byl zárukou toho, že zdejší

15 To je částečně spojeno s pozdní urbanizací, která se ve zdejší oblasti začala aktivněji rozvíjet až s nástupem 12. století. Taktéž christianizace, jejíž počátky se obvykle datují do 10. století, když pomineme éru Slavníkovce Vojtěcha, šla vždy ruku v ruce se státními zájmy, díky čemuž o ní můžeme jen s obtížemi uvažovat jakožto o autonomním aktéru formování státu. Roli církve v této oblasti snižujeme také z jiného důvodu, protože ona sama, přes své světské (politické) zdroje a výsady, nemohla usilovat o prímý transfer mocenských pozic v politě (politické sféře). Mohla se sice ucházet o zlepšení svého postavení ve vztahu k panovnické moci, nicméně tuto moc nemohla na rozdíl od šlechty monopolizovat. V tomto ohledu byla situace výrazně odlišná v jiném středoevropském státě, totiž v Polsku, kam pronikaly rytířské řády ze Západu a budovaly zde vlastní politickomocenskou a v neposledním řadě i vojenskou organizaci. 
knížata mohla vystavět na tehdejší poměry velké vojsko, které znamenalo dostatečnou garanci jejich nezávislosti. ${ }^{16}$ Jelikož se obchod s otroky, zvláště kapitál z něj plynoucí, a budování státu vzájemně umocňovaly, jedno podporovalo druhé, ${ }^{17}$ stát rychle územně expandoval. To se dělo kupř́kladu takovým způsobem, že během necelých patnácti let vlády Boleslava I. ovládnul místní monopol rozsáhlé oblasti střední Evropy, včetně dnešního Slovenska, Slezska či Haliče. Jak však s postupem času, díky sérii vnitřních politických turbulencí (zejména nástupnických sporů o trůn), začal český monopol slábnout a v okolních oblastech začaly být jakožto principy obrany uplatňovány stejné politickoorganizační prvky jako $\mathrm{v}$ přemyslovské řiši, obchod s otroky začínal být stále méně a méně výnosný a nakonec i možný. Souhrou těchto okolností se museli přemyslovští panovníci poohlédnout po jiném zdroji, jenž by byl schopný zajistit financování státu. Díky tomu došlo $\mathrm{k}$ přechodu od kořistnického vojenského státu $\mathrm{k}$ primitivnímu patrimoniálnímu absolutismu, spoléhajícímu se na hradskou soustavu. Z jízdních válečníků, chytajících pro státní účely otroky, se stali správci jednotlivých hradišt', jimiž bylo území Čech (touto dobou ovšem třeba i Moravy) postupně protkáno. Tato sít nejenom, že zajištovala nejenom provádění práva a obrany konkrétních regionů, ale sloužila navíc také výběru daní, které musel platit každý svobodný občan. Nově vzniklý systém byl tedy mnohem více vázaný na zemědělskou ekonomiku než ten předcházející, a díky tomu se stále více podobal tomu, který ve stejné době převládal na Západě. Vzdor tomu všemu se však stále jednalo o systém monopolizovaný státem a nikoli převážně šlechtou. Přechod ve způsobu hospodářské organizace ale znamenal první významný podnět k vytvoření předběžných podmínek pro privatizaci státní moci, nebot nad veškerou „státní “ šlechtou nebylo možné za stávajících technologických podmínek udržovat bedlivou kontrolu [Třeštík 2009; Žemlička 2002a: kap. 6, 2009]. ${ }^{18}$

2. Vzestup okolních státních monopolů. Počínaje polovinou 10. a konče 11. stoletím se střední Evropa stává svědkem zrodu dvou zcela nových státních těles. Jednoho situovaného více severně, tj. domény polských Piastovců, a jednoho více na jihu, tedy arpádovské državy. Jejich vznik byl podobně jako u většiny zdejších států svázán s difúzí a implementací nových institucí, které měly při organizaci společnosti nahradit instituce stávající, jež se ukazovaly být stále méně a méně účinné. Díky extenzi těchto dvou nových monopolů, organizovaných prakticky na stejné bázi, jako tomu bylo v př́ípadě toho přemyslovského,

16 Český historik Dušan Třeštík [2009: 90] se domnívá, že Přemyslovci mohli disponovat armádou se třemi až šesti tisíci jezdci, což byla na tehdejší evropské poměry skutečně významná bojová síla. Takovéto vojsko mohli vystavět a udržovat jen proto, soudí v jiném svém textu Třeštík [1999], že během vlády Boleslava II. se na pražském tržišti prodalo odhadem na 30 až 35000 otroků, což mohlo pro knížete znamenat zisk okolo 10 milionů denárů (asi deset tun čistého stříbra). To je podle našich propočtů při současných burzovních cenách stř́ibra zisk okolo 230 milionů korun. Samozřejmě že o tomto můžeme, ostatně jako o jakémkoliv jiném historickém faktu starém přes tisíc let, do určité míry pochybovat a ptát se, jestli obchod s otroky v tomto období sehrával pro stát důležitější úlohu než zisk nadhodnoty od rolníků.

17 V této úvaze sledujeme poměrně věrně myšlenky Charlese Tillyho [1992] o vztahu mezi koncentrací kapitálu a koncentrací přinucení, která vede k budování státních organizačních struktur.

18 Z prostorových a intencionálních důvodů se na tomto místě nemůžeme podrobněji věnovat fenoménu kontroly v polobyrokratické struktuře přemyslovského státu. Čili tomu, jak se státní šlechta snažila unikat dozoru ze strany panovníka a jeho nejbližších spolupracovníků a jak se dále snažila minimalizovat své odvody do státní pokladny a přitom maximalizovat své vlastní zisky, které prostřednictvím státní struktury plynuly do jejích vlastních kapes. A na druhou stranu, jak se v takovém předivu vztahů kontroly a exploatace zachovával panovník, volící takové strategie, jež by zabraňovaly zmíněným únikům. K podobné myšlence též výše (poznámka pod čarou č. 15). 
došlo k situaci, že se počáteční rychlá expanze přemyslovského státu zabrzdila a ustálila se v přibližně dnešních hranicích České republiky. V tomto ohledu má tedy Elias pravdu, když z jeho názoru vyvodíme, že i rozšiřování zdejšího státního monopolu bylo podmíněno extenzí jiných státních monopolů. K tomuto procesu zde ale docházelo na evropské poměry nesmírně rychle, jelikož zdejší oblast neprodělala feudalizaci, rozdrobení panovnické moci, kterou by pak bylo nutné opětovně scelit.

V kontextu vlivu této nově vzniklé politické makrostruktury - miniaturního mezinárodního systému tvořeného otonskou (později sálskou a štaufskou), arpádovskou, přemyslovskou a piastovskou říší - na monopolní mechanismus pak musíme uvést: za prvé, že každé další rozšiřování územní rozlohy („teritoriální moci“, pakliže bychom používali termínu Randalla Collinse [1999]) v tomto systému bylo spjato s relativní mocí ostatních aktérů. Jestliže se jeden $\mathrm{z}$ nich dostal do potíží, mohli toho zbylí aktéři využít a znásobit svou vlastní moc na jeho úkor. Pokud ovšem hrozilo, že by jeden ze států, jako tomu bylo kupříkladu v prrípadě Polska na začátku 11. století nebo Čech v éře vlády Přemysla Otakara II., měl šanci získat výraznější výhodu na úkor zbylých zemí, tyto se proti němu obvykle rychle spolčily a uzavřely více či méně dočasnou alianci. Docházelo zde tedy - alespoň v éře, jíž se věnujeme - $\mathrm{k}$ mechanismům vyvažování síly jednotlivých států tak, jak jsou popisovány některými autory teorie mezinárodních vztahů [např. Morgenthau 2006; Walt 1990]. Z toho důvodu se také domníváme, že projekt všeslovanského státu, tzv. Slavinie, coby protiváhy německé moci, jak o něm ve své knize Zrod střední a východní Evropy svého času uvažoval František Dvorník [1999 (1974)], neměl již od počátků př́liš mnoho šancí na úspěch. Za druhé, tento systém prakticky zamezil pokračování existence kořistnického státu tím, že mu namísto kmenových struktur 9. a první půle 10. století postavil do cesty organizované a relativně centralizované státní aparáty, díky čemuž se musely zdejší státní monopoly spoléhat na jiný druh zisku kapitálu. Tento bod tedy úzce koreluje s proměnou zdejšího hospodářství.

3. Nárůst sily patrimoniální šlechty a počátky její emancipace. Jak staletí plynula, začali být státní úřredníci, $\mathrm{v}$ tomto prrípadě správcové hradů, $\mathrm{z}$ nichž stát vykonával svou moc, stále méně závislí na ústřední státní moci. Dá se říci, že s každou výraznou destabilizací přemyslovského panství, vyvolanou nároky říšských (popřípadě piastovských) vladařu či s každým dalším pokusem o puč a převzetí moci jiným Přemyslovcem, získávala patrimoniální šlechta nemalé výhody pro sebe. Nejenom že na ní byli panovníci stále více závislí, jelikož byla jejich jediným spojencem, navíc dokázali místní držitelé moci část státních důchodů, které plynuly do jejich kapes, znovu investovat do rozšiřování svého vlastního majetku. To bylo zvláště důležité, když začalo ve 12. století docházet ke kolonizačním procesům [viz Žemlička 2002a: 272nn, 2009: 212]. Následkem toho pak vznikala jakási dvojí mocenská struktura: jedna veřejná, reprezentující stát a jeho zájmy, a druhá soukromá, zastupující zájmy velmožských rodů. Stát a jeho šlechtický dvojník tak existovaly, vyrůstaly a umíraly vedle sebe po velkou část 12 . století, aby byl jejich vztah nakonec reglementován podpisem Konrádových statut (Statuta ducis Ottonis) r. 1189, stvrzujících (mimo mnohá jiná důležitá nařízení) dědičnost majetku tehdejší patrimoniální šlechty [srov. též Wihoda 2006: 70]. Zdroje státu se tak začaly poprvé významně štěpit, bylo proto jen otázkou času, kdy tyto procesy dosáhnou takové úrovně, že překročí práh, po němž i ta po jehož překročení i zbylá státní moc bude privatizována a stane se kompletním vlastnictvím místních šlechtických rodů. Tento vývoj také přispěl k tomu, že nově se formující šlechta začala 
jednat více coby korporátní aktér, tedy jakožto stav hájící své zájmy vůči Koruně, čímž se též misky vah politického konfliktu začaly naklánět stále více na stranu střetů panovníků $\mathrm{s}$ aristokracií.

Postupným spolupơsobením uvedených faktorů tedy došlo k tomu, že se původně relativně centralizovaný státní monopol začal štěpit a stále více připomínat feudální „ne-stát“. To všechno se dělo tehdy, když v západním výběžku kontinentu pomalu docházelo k přesně opačným tendencím: objevovaly se první ustálené centralizované mocenské struktury monopolizující si prostředky přinucení, jádra francouzského a anglického státu (viz výše). Charakter státní organizace se tak v obou částech Evropy převrátil. Mezi českými historiky však nepanuje shoda na tom, kdy k onomu konečnému rozštěpu, rozkladu zdejšího státu, vlastně došlo. Podle některých jím byl již rok 1189 [Agnew 2008: 43; Žemlička 2009], ${ }^{19}$ podle jiných teprve vláda Přemysla Otakara I. [Wihoda 2006] a podle jiných až nástup Jana Lucemburského na královský trůn [Libor 2006]. Celou věc navíc komplikují dvě okolnosti: jednak se éra privatizace státní moci shoduje s dobou, v níž Přemyslovci získali pro své knížectví status dědičné královské državy, a tím i zcela legitimní a nezávislou pozici v mezistátním systému, což interpretaci relativní síly státu poněkud zastírá, zároveň ale vedle sebe moc státní a šlechtická po dlouhou dobu vzájemně koexistovaly, aniž by vzestup jedné znamenal zánik té druhé. V prvním př́ípadě můžeme uvést, že sice došlo $\mathrm{k}$ nárůstu legitimity mocenského monopolu ve směru navenek, především ve vztahu k Říši, na druhou stranu však ve vztahu k vnitřním silám došlo k výraznému poklesu moci v rukou státu. Zatímco proti vnějším intervencím byl stát obranyschopnější než kdy dříve, ve vztahu ke šlechtické opozici své pozice nezvratně ztrácel. V druhém případě je třeba dodat, že pro panstvo nebyl okamžitý zánik státu - podobná kompletní destrukce, k níž došlo na Západě v 9. století - nijak výhodný, nebot by tím tato část šlechty přišla o jednoho z garantů své vlastní ochrany proti zahraničním agresorům. Co víc, nesmíme zapomínat na to, že stálá existence státu, byt již notně privatizovaného, představovala pro šlechtické rody nezanedbatelný zdroj př́ijmů, na němž mohla různou měrou participovat (parazitovat). Spíše tedy velmi pomalý úpadek a rozklad centralizovaných státních struktur než radikální svržení předcházejícího politického řádu charakterizují průběh úpadku přemyslovského monopolu.

\section{Determinanty přemyslovského monopolu}

Rozhodující silou, podle Eliasova soudu brzdící či urychlující podle Eliasova soudu formování států, zůstávají přírodní podmínky, které v př́padě přemyslovského monopolu sehrály ambivalentní roli. Tisícimetrové horské výběžky obklopující českou kotlinu na jednu stranu sice vytvářely ideální základnu pro rychlé zformování státního monopolu, činily z něj pomyslný suchozemský ostrov uprostřed střední Evropy, na druhou stranu dávaly určitý limit jeho dalšímu rozpínání. Šumava, Krkonoše a Orlické hory tak z části představovaly jakousi přirozenou hradbu vůči vnějším vpádům, částečně ale také znesnadňovaly dlouhodobé rozšiřování územních držav za perimetr tohoto přirozeného přírodního systému; učinily jeho další rozšiřování mnohem nákladnějším, než byly zisky, jež z něj plynuly. I z tohoto důvodu, obzvláště když k tomu připočteme sílu německého

19 Ačkoliv ten jej v jiných svých textech řadí až do 13. století [viz Žemlička 2002a: 364 a 411nn; 2002b: kap 4; 2003]. 
státu, česká expanze mířila vždy spíše východním směrem. To je ostatně rovněž zóna, do níž směřovala své výpady generace Boleslavů na českém trůně. Jak jsme však zmínili, rozhodující roli v geografickém utváření místního monopolu sehrálo rozpínání dalších středoevropských států a vytvoření vzájemně propojeného středoevropského mikrostátního systému v 11 . století. Na něm od této doby fakticky záležely veškeré posuny územní moci.

V naznačeném rámci bychom měli samozřejmě odpovědět na otázku, zdali bylo dlouhodobé udržení Moravy promyšleným plánem přemyslovských vladařuo, anebo spíše nezamýšleným důsledkem předcházející výbojné politiky Boleslavů na českém trůně. At̉ už to bylo tak či onak, Morava posloužila Přemyslovcům, počínaje 11. stoletím, významným způsobem tím, že na jejím území vznikla struktura údělných lén, která řešila hned dvojí problém: 1. tato léna částečně tlumila střety o knížecí post tím, že propůjčovala významné postavení ve státní správě i dalším členům vládnoucí dynastie, kteří by jinak o to častěji vyvolávali spory o nástupnictví v Čechách; 2 . tato struktura rozmělnila původně koncentrovanou vojenskou sílu, která již nebyla potřebná k loupeživým tažením, a tudíž pro ni neexistovalo přímé uplatnění. Zmíněné jednotky tak nakonec posloužily jako základ státní (hradské) správy i mimo českou kotlinu [Třšstík 2009].

\section{Závěr, aneb několik cest evropské sociogeneze}

Jestliže tedy srovnáváme sociogenezi raného českého státu s teorií Norberta Eliase, potažmo s formačními procesy v Anglii a Francii, zjištujeme, že se v mnoha ohledech liší. Procesy utváření přemyslovského státu totiž probíhaly přesně opačným směrem, než měly podle Eliase probíhat: pohyb od decentralizovaného stavu ke stavu centralizovanému zde byl nahrazen vývojem od centralizovaného státního monopolu k decentralizovanému. ${ }^{20}$ Tento klíčový rozdíl způsobila celá řada faktorů, mezi nimiž bychom měli jmenovat především umístění zdejšího státu mimo prostor bývalého Imperia Romana, dále difúzi politicko-organizačních principů z Velké Moravy a také relativně vysokou počáteční koncentraci kapitálu v rukou panovníků, zprostředkovanou obchodem s otroky. Taktéž aktéři zapojení do zdejšího monopolního mechanismu - do principiálního souboje o moc ve státě - zde byli jiní, tak zejména církev a města sehrávala v letech 860 až 1230 oproti jiným politickým silám spíše druhořadou roli. Nicméně je třeba rovněž uvést, že rok, jímž končíme náš výzkum, není spojen s kompletní destabilizací moci českého státu. Jeho decentralizace, pokračující především po celé 13. století, nedosáhla nikdy takového stupně, aby stát kompletně zanikl, což je ostatně také hlavní rozdíl mezi českou decentralizací a tou, $\mathrm{k}$ níž došlo o čtyři století dříve v prostoru bývalé Franské říše. V neposlední řadě bychom měli zmínit, že ani demografické procesy zde nesehrávaly takovou úlohu, jakou bychom podle Eliasovy teorie čekali. Formování státu

20 Takovéto tvrzení si můžeme dovolit vyslovit pouze proto, že je formulujeme pro přesný časoprostorový rámec. Pakliže bychom o něm hovořili na úrovni obecných dějin, bylo by asi vhodnější uvažovat o střídání a pravděpodobně i prolínání centralizačních a decentralizačních tendencí. Měli bychom pak mít na paměti, že v tomto ohledu navíc uvažujeme pouze o centralizaci a decentralizaci politické moci (monopolu na přinucení, jestliže budeme věrně následovat Weberovy myšlenky), a nikoliv o centralizaci či decentralizaci ekonomické moci, jak o ní jakožto o autonomním mocenském zdroji uvažují někteří jiní autoři [Giddens 1985; Mann 1986; Tilly 1992]. Dokonce zde ani neuvažujeme o centralizaci/decentralizaci symbolické moci, jíž se v některých svých úvahách věnuje Pierre Bourdieu [1994, 1998: kap. 4]. Každý z těchto aspektů/projevů formování států se tedy vyznačuje svou vlastní, do určité míry nezávislou dynamikou. 
Přemyslovců rozhodně nebylo doprovázeno hladem po půdě, ba právě naopak se stalo cílem německé kolonizace 12. a 13. století, která měla mít v budoucnu některé velmi důležité konsekvence, překračují však námi vymezený časový rámec.

Případ utváření českého knížectví nejenom že vyvrátil některé z Eliasových premis, mnohé na druhou stranu též potvrdil. Zejména jeho tezi o závislosti územního rozšiřování státních monopolů na extenzi jiných státních monopolů, která se zdá být v případě přemyslovské domény platná. Nicméně bychom ji přesto mohli doplnit o poukaz, že ke střetu expandujících (státních) monopolů došlo ve střední Evropě mnohem rychleji nežli na Západě, nebot’ ani jeden z nich neprodělal v té době feudalizaci. Díky tomu, že místní státy již představovaly mocenské monopoly a ne feudální polostáty, urychlil se jejich vzájemný stř̌et a následná taktéž vzájemná stabilizace. Podobně i zeměpisné podmínky sehrály v př́padě přemyslovské državy svou podstatnou roli, ačkoliv byl jejich význam podle našeho soudu rozhodně vyšší v 9. až 11. století nežli později, kdy začaly tón vývoje udávat mezinárodní vztahy.

Jestliže na tomto místě ted' shrneme závěry naší studie a pokusíme se je zobecnit, můžeme zformulovat šestici bodů, jež by mohly sloužit $\mathrm{k}$ doplnění a částečné reformulaci teorie sociogeneze Norberta Eliase:

1. Proces sociogeneze nemírí vždy od decentralizovaného stavu ke stavu centralizovanému. Přinejmenším ve střední Evropě (v českém, polském a uherském státě raného a vrcholného středověku) probíhaly formační procesy opačným směrem a vedly k postupné destabilizaci a privatizaci státní moci.

2. Procesy utváření státu vně bývalého Limes Romanum mají odlišné charakteristiky než ty, které probíhaly uvnitř jeho hranic. Státy nacházející se mimo jeho dosah dlouhodobě postrádaly post-antické organizační struktury, což je vedlo k poněkud odlišné formě politické organizace.

3. Tato forma organizace byla $\mathrm{z}$ počátku úzce svázána $s$ kořistnickou ekonomikou (ta možná, krom jiných faktorů, souvisí i se skandinávským formováním států v témže období). Díky kořistnické ekonomice si byly některé rané evropské státy schopny vytvořit a udržovat velmi centralizovanou správní strukturu, a to mnohem rozvinutější než ty státy, které se nacházely v zóně vlivu bývalé Říše římské. Centralizovaná státní struktura byla také o něco později, přes úpadek kořistnické ekonomiky, udržována za pomoci tzv. hradské soustavy, připomínající v mnoha ohledech zř́izení patrimoniálního absolutismu.

4. Počáteční procesy sociogeneze ve střední Evropě probíhaly, díky absenci předcházejících státních struktur, mnohem rychleji než na Západě.

5. Hlavní aktéři monopolního mechanismus se mohou v různých oblastech evropského světadílu lišit. Církev a měštanstvo sehrávalo ve střední Evropě v éře 9. až 13. století rozhodně méně významnou roli než při formování státu na Západě, což ostatně platí i pro některé z dalších částí Evropy: Německo, Skandinávii aj. Také šlechta, pakliže byla již z počátku integrována do státního aparátu coby patrimoniální úřednictvo, nemusela být ihned principiálním soupeřem panovnické moci.

6. Demografické procesy ovlivňují sociogenezi též nerovnoměrně a jsou do ní během námi sledované časové sekvence zapojeny mnohem intenzivněji v západní části kontinentu než v té východní. Tento stav byl zapříčiněn výrazně nižší lidnatostí východní Evropy oproti té západní. 
Uvedený výčet vývojových bodů si samozřejmě nečiní nárok na úplnost, nicméně vytváří přinejmenším zajímavý odrazový můstek pro zkoumání sociogeneze v dalších evropských oblastech, zvláště pak ve střední a východní Evropě (například na území států Čechám nejbližším, tj. Polsku a Uhrám, nebo na př́kladech dnešní Ukrajiny, pobaltských států či Ruska) a Skandinávii. Jinak řečeno stává se mostem sloužícím k případnému synchronnímu srovnání formačních procesů během 9. až 13. století. Dalším postupem, jenž se v tomto kontextu nabízí, je pokračování v diachronním typu analýzy sociogeneze českého státu, včetně jeho následné komparace s Eliasovou teorií. At̉ ta či ona cesta, každá z nich představuje pokračování teoretického programu, který jsme v náznacích načrtli hned v úvodu této stati: tj. důslednou sociologickou teoretizaci historie a její zpětnou, neméně důkladnou historizaci.

\section{Literatura}

Abu-Lughod, J. [1989]. Before European Hegemony. The World System A.D. 1250-1350. New York, Oxford: Oxford University Press.

Agnew, Hugh, L. [2008]. Češi a země Koruny české. Praha: Academia.

Andreski, Stanislaw. [1968]. Military Organization and Society. Berkeley, Los Angeles: University of California Press.

Arnason, Johann P. [2010]. Historicko-sociologické eseje. Praha: SLON.

Bacci, Massimo Livi. [2003]. Populace v evropské historii. Praha: NLN.

Bartlett, Robert. [1994]. The Making of Europe. Conquest, Colonization, and Cultural Change 950-1350. London, New York: Penguin Books.

Belandier, Georges [2000 (1967)]. Politická antropologie. Praha: Dauphin.

Bourdieu, Pierre. [1994]. Rethinking the State: Genesis and Structure of the Bureaucratic Field. Sociological Theory 12 (1), pp. 1-18.

Bourdieu, Pierre. [1998]. Teorie jednání. Praha: Karolinum.

Burkhardt, Jacob. [1971 (1905)]. Úvahy o světových dějinách. Praha: Melantrich.

Clasters, Pierre. [1977]. Society Against the State. Oxford: Blackwell.

Claessen, Henry, J. M. - Skalnik, Peter (eds). [1978]. The Early State. Hague: Mouton Publisher.

Collins, Randall. [1999]. Macrohistory. Essays in Sociology of the Long Run. Stanford, Calif.: Stanford University Press.

Diamond, Jared. [2001]. Osudy lidských společností. Střelné zbraně, choroboplodné zárodky a ocel v historii. Praha: Columbus.

Dvorník, František. [1999 (1974)]. Zrod střední a východní Evropy. Mezi Byzancí a Římem. Praha: Prostor.

Duby, Gerorges. [2003]. Dějiny Francie. Praha: Karolinum.

Duby, Georges. [2008]. Tři řády. Praha: Argo.

Eisenstadt, Shmuel N. [2000]. Multiple Modernities. Daedalus 129 (1), pp. 1-30.

Elias, Norbert. [1978]. On Transformations of Aggressiveness. Theory and Society 5 (2), pp. 229-242.

Elias, Norbert. [2006]. O procesu civilizace. Díl I. Praha: Argo.

Elias, Norbert. [2007]. O procesu civilizace. Díl II. Praha: Argo.

Ertman, Thomas. [2000]. Birth of Leviathan: Building States and Regimes in Medieval and Early Modern Europe. Cambridge, Mass., Harvard University Press.

Fountaine, Stephen. [1978]. The Civilizing Process Revisted: Inteview with Norbert Elias. Theory and Society 5 (2), pp. 243-253.

Freud, Sigmund. [1998 (1930)]. Nespokojenost v kultuře. Praha: Hynek.

Galuška, Luděk. [2003]. O otrocích na Velké Moravě a okovech Starého města. In. Klápště, Jan - Plešková, Eva - Žemlička, Josef (eds). [2003]. Dějiny ve věku nejistot: Sborník k př́ležitosti 70. narozenin Dušana Treštíka. Praha: NLN. 
Gellner, Ernest. [1993]. Národy a nacionalismus. Praha: Josef Hříbal.

Giddens, Anthony. [1985]. Nation State and Violence. Second Volume of Contemporary Critique of Historical Materialism. Cambridge: Polity Press.

Gorski, Philip, S. [2003]. Disciplinary Revolution: Calvinism, Confessionalism and the State Formation in Early Modern Europe, 1500-1750. Chicago, University of Chicago Press.

Havlík, Lubomír. [1992]. Kronika o Velké Moravě. Brno: Jota.

Hintze, Otto. [1975]. The Historical Essays of Otto Hintze. New York: Oxford University Press.

Holubec, Stanislav. [2009]. Sociologie světových systémů: Hegemonie, centra, periferie. Praha: SLON.

Charvát, Petr. [2007]. Zrod českého státu. 568-1055. Praha: Vyšehrad.

Keller, Jan. [2009]. Nejistota a di̊věra aneb K čemu je modernitě dobrá tradice. Praha: SLON.

Kiser, Edgar - Drass, Kriss, A. - Brustein, William. [1995]. Ruler Autonomy and War in Early Modern Western Europe. International Studies Qurterly 39 (1), pp. 109-138.

Kiser, Edgar; Baer, John. [2005]. The Bureaucratization of States: Toward an Analytical Weberism. In. Adams, Julia. - Clemens, Stephanie - Orloff, Anna S. (eds). Remaking Modernity: Politics, History, and Sociology. Duke University Press.

Klápště, Jan. [2009]. Evropa, stř̌ední Evropa a české země. In. Somer, Petr - Třeštík, Dušan - Žemlička, Josef (eds). Přemyslovci a budování českého státu. Praha: NLN.

Kuhn, Thomas. [1997]. Struktura vědeckých revolucí. Praha: OIKOIMENH.

Libor, Jan. [2006]. Václav II. Struktury panovnické moci. Brno: Matice moravská.

Mann, Michael. [1986]. The Sources of Social Power. Vol. I.: A History of Power from Beginning to AD 1760. Cambridge: Cambridge University Press.

Marx, Karel; Engels, Bedřich [1952]. Německá ideologie. Praha: Svoboda.

Mennell, Stephen. [1989]. Norbert Elias: Civilization and the Human Self-Image. Oxford: Basil Blackwell.

Mertuccelli, Danilo. [2008]. Sociologie modernity. Itinerár 20. století. Brno: CDK.

Moore, Barrington, Jr. [1966]. Social Origins of Dictatorship and Democracy: Lord and Peasant in the Making of the Modern World. Boston: Beacon Press.

Morgenthau, Hans, J. [2006]. Politics Among Nations. The Struggle for Power and Peace. Revisted by Thomas, K. W; Clinton, W. D. Boston: McGraw-Hill.

Parsons, Talcott. [1971b]. The System of Modern Societies. Englewod Cliffs, New Jersey: Prentice-Hall, Inc.

Poggi, Gianfranco. [1978]. The Development of the Modern State. A Sociological Introduction. Stanford, Calif:: Stanford University Press.

Popper, Karl, R. 1998. Život je řešení problémů. O poznání, dějinách a politice. Praha: Mladá fronta.

Reynolds, Susan. [1997]. The Historiography of the Medieval State. In. Bentley, Michael. (ed.). 1997. Companion to Historiography. London, New York: Routledge.

Reynolds, Susan. [2003]. There were States in Medieval Europe. The Journal of Historical Sociology 16 (3), pp. 550-555.

Rokkan, Stein. [1975]. Dimensions of State Formation and Nation-Building: A Possible Paradigm for Research on Variations Within Europe. In. Tilly, Charles. (ed.). 1975. The Formation of National States in Western Europe. Princeton: Princeton University Press.

Skocpol, Theda. [1979]. States and Social Revolutions. Cambridge: Cambridge University Press.

Smith, Dennis. [2001]. Norbert Elias and Modern Social Theory. London - Thousand Oaks - New Dehli: Sage Publications.

Strayer, Joseph R. [1971]. Medieval Statecraft and the Perspectives of History. Princeton, New Jersey: Princeton University Press.

Szakolczai, Árpád. [2000]. Reflexive Hisotrical Sociology. London, New York: Routledge.

Šubrt, Jiř́. [1996]. Civilizační teorie Norberta Eliase. Praha: Karolinum.

Šubrt, Jiř́i. [2007]. Norbert Elias a jeho dílo O procesu civilizace. In. Šubrt, Jiř́i. (ed.). Historická sociologie. Teorie dlouhodobých vývojových procesủ. Plzeň: Vydavatelství a nakladatelství Aleš Čeněk s.r.o.

Šubrt, Jiří. [2008]. „Dialog mezi hluchými“? K problematice vztahu sociologie a historie. Sociologický časopis 44 (5), s. 969-988.

Tainter, Joseph A. [2009]. Kolapsy složitých společností. Praha: Dokořán.

Teschke, Benno. [2003]. Myth of 1648. Class, Geopolitics and Making of Modern International Relations. London: Verso. 
Teschke, Benno. [2004]. The Origins and Evolution of the European State-System. In. Brown, William Bromley, Simon - Athreye, Suma (eds). Ordering the Interantional: History, Change, and Tranformation. London - Chicago: Pluto Press.

Tilly, Charles. [1975]. Reflection on the History of European State-making. In. The Formation of National States in Western Europe. Princeton: Princeton University Press.

Tilly, Charles [1992]. Coercion, Capital, and European States AD 990-1992. Oxford: Blackwell Publishing.

Třeštík, Dušan. [1987]. Pád Velké Moravy. In. Typologie raně feudálních slovanských států. Praha: Ústav československých a světových dějin.

Třeštík, Dušan. [1999]. Kdo zaplatil vznik českého státu? Dějiny a současnost 21 (3), s. 2-7.

Třeštík, Dušan. [2001]. Vznik Velké Moravy. Moravané, Čechové a střední Evropa v letech 791-871. Praha: NLN.

Třeštík, Dušan. [2006]. Počátky přemyslovské státnosti mezi křestanstvím a pohanstvím. In. Wihoda, Martin - Malaták, Demeter (eds). 2006. Stát, státnost a rituály přemyslovského věku. Brno: Matice moravská.

Třeštík, Dušan. [2008]. Počátky Přemyslovců. Vstup Čechů do dějin (530-935). Praha: NLN.

Třeštík, Dušan. [2009]. Od prŕíchodu Slovanů k „říši“ českých Boleslavů. In. Somer, Petr - Třeštík, Dušan Žemlička, Josef (eds). 2009. Přemyslovci a budování českého státu. Praha: NLN.

Walt, Stephen. [1990]. The Origins of Aliances. Ithaca, New York: Cornell University Press.

Weber, Max. [1998 (1922)]. Metodologie, sociologie a politika. Praha: OIKOIMENH.

Wihoda, Martin. [2006]. První české království. In. Wihoda, Martin - Malaták, Demeter (eds). 2006. Stát, státnost a rituály přemyslovského věku. Brno: Matice moravská.

Whitt, Hugh, P. [2010]. The Civilizing Process and Its Discontents: Suicide and Crimes against Persons in France, 1825-1830. American Journal of Sociology 116 (1), pp. 130-186.

Žemlička, Josef. [2002a]. Čechy v době knižecí, 1034-1198. Praha: NLN.

Žemlička, Josef. [2002b]. Počátky Čech královských, 1198-1253. Praha: NLN.

Žemlička, Josef. [2003]. České 13. století a „privatizace“ státu. Český časopis historický 101, s. 509-540.

Žemlička, Josef. [2009]. Společnost v područí státu. In. Somer, Petr - Třeštík, Dušan - Žemlička, Josef (eds). Přemyslovci a budování českého státu. Praha: NLN.

Jan Kalenda je interním doktorandem Katedry sociologie a andragogiky Univerzity Palackého v Olomouci. Odborně se věnuje problematice historické sociologie, zvláště pak aspektům evropského formování států, sociologii války a revolucí. 